\title{
Ecosystem health assessment of three inland water bodies in South-west, Nigeria based on fish diversity, pollution status, ecological and health risk indices
}

Prince Emeka Ndimele ( $\nabla$ emeka.ndimele@lasu.edu.ng )

Lagos State University Faculty of Science https://orcid.org/0000-0001-5890-3374

Fatai Gbolahan Owodeinde

Lagos State University Faculty of Science

Abdullatif 0 Giwa-Ajeniya

Lagos State University Faculty of Science

Bridget A. Moronkola

Lagos State University Faculty of Science

Oyindamola R. Adaramoye

Lagos State University Faculty of Science

Lois O. Ewenla

Lagos State University Faculty of Science

Hijrah Y. Kushoro

Lagos State University Faculty of Science

Research Article

Keywords: Ecosystem health, ecotoxicology, health risk, physico-chemistry, condition factor

Posted Date: February 18th, 2021

DOI: https://doi.org/10.21203/rs.3.rs-201850/v1

License: (c) (i) This work is licensed under a Creative Commons Attribution 4.0 International License.

Read Full License 


\section{Ecosystem health assessment of three inland water bodies in South-west, Nigeria based on fish diversity, pollution status, ecological and health risk indices}

Ndimele, P.E*' ${ }^{*}$ Owodeinde, F.G. ${ }^{1}$; Giwa-Ajeniya, A.O. ${ }^{2}$; Moronkola, B.A. ${ }^{2}$; Adaramoye, O.R. ${ }^{1}$; Ewenla, L.O. ${ }^{1}$ and Kushoro, H.Y. ${ }^{1}$

${ }^{1}$ Department of Fisheries, Faculty of Science, Lagos State University, Ojo, Lagos State.

${ }^{2}$ Department of Chemistry, Faculty of Science, Lagos State University, Ojo, Lagos State.

*Correspondence: emeka.ndimele@ lasu.edu.ng; drpendimele@ yahoo.com

\section{Abstract} Mobile: 08038205109

This study was conducted to determine the health status of three water bodies (Badagry Creek, Ologe Lagoon and River Owo) because of the large amount of effluent they receive from industries around Lagos as well as the services they provide to sustain the large human population in an emerging mega city like Lagos. Water, sediment and fish samples were collected monthly from the three water bodies between January and December, 2018. Standard methods were used for the analysis of physico-chemical parameters, heavy metals, length-weight relationship, condition factor, fish diversity indices, sediment pollution indices, ecotoxicology of heavy metals in sediment and potential ecological risks as well as health risk assessment of heavy metals. The geoaccumulation index (Igeo) of heavy metals in sediments of the sampling sites ranged from 12.14 to -0.38 . The mean quotients using the probable effect level (m-PEL-Q) are 3.91 x10-4, 4.77 x10-4 and 7.87 x10-4 for Ologe Lagoon, Badagry Creek and River Owo respectively. The trend was the same with mean quotients using effect range-median (m-ERM-Q). The estimated daily intake (EDI) ranged from $0.00 \mathrm{mgkg}-1$ day- 1 in Pb from River Owo to 1.15 x10-3 mgkg-1day-1 in Fe still from River Owo. The range of values of the target hazard quotient (THQ) of the metals in Badagry Creek, River Owo and Ologe Lagoon are 1.23x10-4 - 1.65x10-2, $0.00-1.64 \times 10-2$ and $5.76 \times 10-5-1.65 \times 10-2$ respectively. The study showed that the three aquatic ecosystems are healthy but require regular monitoring to promptly detect sudden changes in their health status.

Findings: The three aquatic ecosystems are healthy but they require regular monitoring to promptly detect sudden changes in their health status.

Keywords: Ecosystem health, ecotoxicology, health risk, physico-chemistry, condition factor

Acknowledgements: Authors are grateful to anonymous reviewers who worked on the manuscript and fishers who assisted in sample collection at the sites. This study was approved by the Research and Ethics Committee of the Faculty of Science, Lagos State University, Ojo, Lagos State, Nigeria. The authors have no conflict of interest. 


\subsection{INTRODUCTION}

Nigeria has maintained a reasonable level of industrialization despite the unfavourable conditions prevalent in the country. About $60 \%$ of the populace are without electricity (Aliyu et al., 2015), the transport system is poor and the roads are in deplorable conditions. This minimal industrial growth is propelled by government's policy to diversify the country's mono-economy which depends largely on crude oil. The result is increase in agricultural and industrial activities in the country. This industrial growth is not widespread but is concentrated in some cities in the country like Abia, Anambra, Kano, Ogun and Lagos states (Oyelaran-Oyeyinka, 1997). Until recently, Lagos state accounts for about $60 \%$ of industrial activities in Nigeria. However, the neighbouring Ogun state is the emerging industrial hub in the country and has equaled or even surpassed industrial activities in Lagos state. The wastes generated by these companies are a major concern for ecologists and environmentalists because of inappropriate waste disposal mechanisms. In most cases, the wastes are emptied into natural water bodies without treatment, and this could endanger the lives of man and aquatic organisms that live in these aquatic ecosystems and depend on them for sustenance. The implication of this is that the ecosystem services provided by these water bodies are threatened and can actually be lost. One of the main components of industrial effluent is heavy metal.

Heavy metals are elements that occur naturally at different concentrations in all ecosystems (Ndimele and Kunolu-Johnson, 2012). They occur in both elemental forms and as components of chemical compounds. Volatile heavy metals and those that adsorb to particles can be transported widely across food chains and ecosystems. Heavy metals can have dietary role in which case they are important in enzymatic and biological processes in animals at low concentration but becomes toxic at high concentration (Kumolu-Johnson et al., 2010). Examples are $\mathrm{Cu}, \mathrm{Co}, \mathrm{Zn}, \mathrm{Fe}$ and $\mathrm{Mn}$. The non-dietary heavy metals play no known function in biological systems and are toxic even at low concentration. Metals in this category are $\mathrm{Hg}, \mathrm{As}, \mathrm{Cd}$ and $\mathrm{Pb}$. The toxicity of metal is influenced by its chemical form (Ndimele et al., 2009). For instance, elemental (inorganic) mercury is not as toxic as the organic forms. The methylation of mercury makes it fat-soluble and in this form, it is able to penetrate biological systems, consequently becoming more toxic and harmful. Heavy metals are non-biodegradable substances and as such persist in different compartments (water, sediment and biota) of the aquatic ecosystem causing various ailments like congenital malformation (Iavicoli et al., 2009), low intelligent quotient in children (Ndimele et al., 2009), cancer (Yoshida et al., 2004) and genetic alteration (Asano et al., 2000). Therefore, heavy metals are major threat to the integrity or health of aquatic ecosystems.

Since the emergence of the concept of ecosystem health in the 1980s, various attempts have been made to define and quantify it. Definition of the concept has not been particularly easy because of 
the dynamic nature of aquatic ecosystems. However, there is a consensus opinion on what a healthy ecosystem should be (Palmer and Febria, 2012). Ecosystem health assessment methods have also varied and in most cases depended on research objectives, available resources and the discipline of the authors, with the last factor being the most influential of the three. Ecosystem health can be measured using physical, chemical or biological indices either singly or in combination (O'Brien et al., 2016). Examples of physical and chemical indices of ecosystem integrity are flow and channel morphology/dimension (in freshwater studies only), physico-chemistry and nutrient status (estuarine and freshwater studies), while biological indices used are species abundance, biodiversity and tolerance (Vilmi et al., 2016). Ecosystem health can also be measured by the ability of the ecosystem to maintain its structure and function (respiration, primary productivity, metabolism and decomposition) in the face of external stressors (O'Brien et al., 2016). Still, others view ecosystem health as the capacity of the ecosystem to provide services (nutrient recycling, drinking water, supply of food, etc) to humans (Keeler et al., 2012).

In recent times, there has been increased pressure on maintaining aquatic ecosystem health by adopting sustainable exploitation approaches because of the enormous roles played by water bodies to sustain human lives. This renewed interest stem from the fact that over $50 \%$ of the global population live within three kilometers of freshwater ecosystems (Kummu et al., 2012) and most of the mega cities in the world are situated on estuaries (Johnston et al., 2015). However, in SubSaharan Africa, very few studies have been conducted to measure ecosystem health (O'Brien $e t$ $a l ., 2016)$. The present study is an attempt to bridge this gap by using multiple indices to determine the health status of Lagos Lagoon complex, which receives effluents from industries located in Lagos State, Nigeria.

\subsection{MATERIALS AND METHODS}

\subsection{Study Area:}

In order to assess the ecosystem health of part of Lagos Lagoon complex, three sites were selected based on proximity to industrial site, presence of the test organism (Coptodon zillii), domestic and fishing activities. The three sites are Ologe Lagoon, Badagry Creek and River Owo (Figure 1). Ologe Lagoon is a freshwater body with surface area of $64.5 \mathrm{~km}^{2}$. It lies between latitudes $6^{\circ} 27^{\prime} \mathrm{N}$ and $6^{\circ} 30^{\prime} \mathrm{N}$; and longitudes $3^{\circ} 02^{\prime} \mathrm{E}$ and $3^{\circ} 07^{\prime} \mathrm{E}$ (Ndimele and Kumolu-Johnson, 2011). Badagry Creek lies between latitudes $6^{\circ} 22^{\prime} \mathrm{N}$ and $6^{\circ} 42^{\prime} \mathrm{N}$; and longitudes $2^{\circ} 42^{\prime} \mathrm{E}$ and $3^{\circ} 42^{\prime} \mathrm{E}$ (Ndimele, 2012). River Owo is a stream located in South-west, Nigeria. Its estimated elevation above sea level is $6.0 \mathrm{~m}$ and its coordinates are: latitude $6^{\circ} 12^{\prime} \mathrm{N}$ and $6^{\circ} 33^{\prime} \mathrm{N}$ and longitude $3^{\circ} 12^{\prime} \mathrm{E}$ and $3^{\circ}$ $48^{\prime} \mathrm{E}$ (Ndimele et al, 2017).

\subsection{Methodology}

2.2.1 Physico-chemistry: Water sampling was carried out once every month for twelve months (January to December, 2018) at the sampling sites. The water samples were collected in 1.5 litre plastic bottles previously cleaned by soaking in nitric acid solution. Samples were stored immediately after collection in a cooler to ensure that the physical properties of the water samples were maintained. Temperature, $\mathrm{pH}$, conductivity, salinity, turbidity and dissolved oxygen of samples were measured in-situ using a mercury-in-glass thermometer, digital $\mathrm{pH}$ meter (model: 
Hanna HI98107), HACH-HQ40D portable multi-meter, turbidity meter (HACH 2100Q) and portable dissolved oxygen meter (HI9146) respectively. Ammonia, total suspended solids (TSS), total dissolved solid (TDS), total solid (TS), total alkalinity, biochemical oxygen demand (BOD), carbon dioxide, and chlorophyll were determined in the laboratory using methods described by American Public Health Association (APHA, 1985).

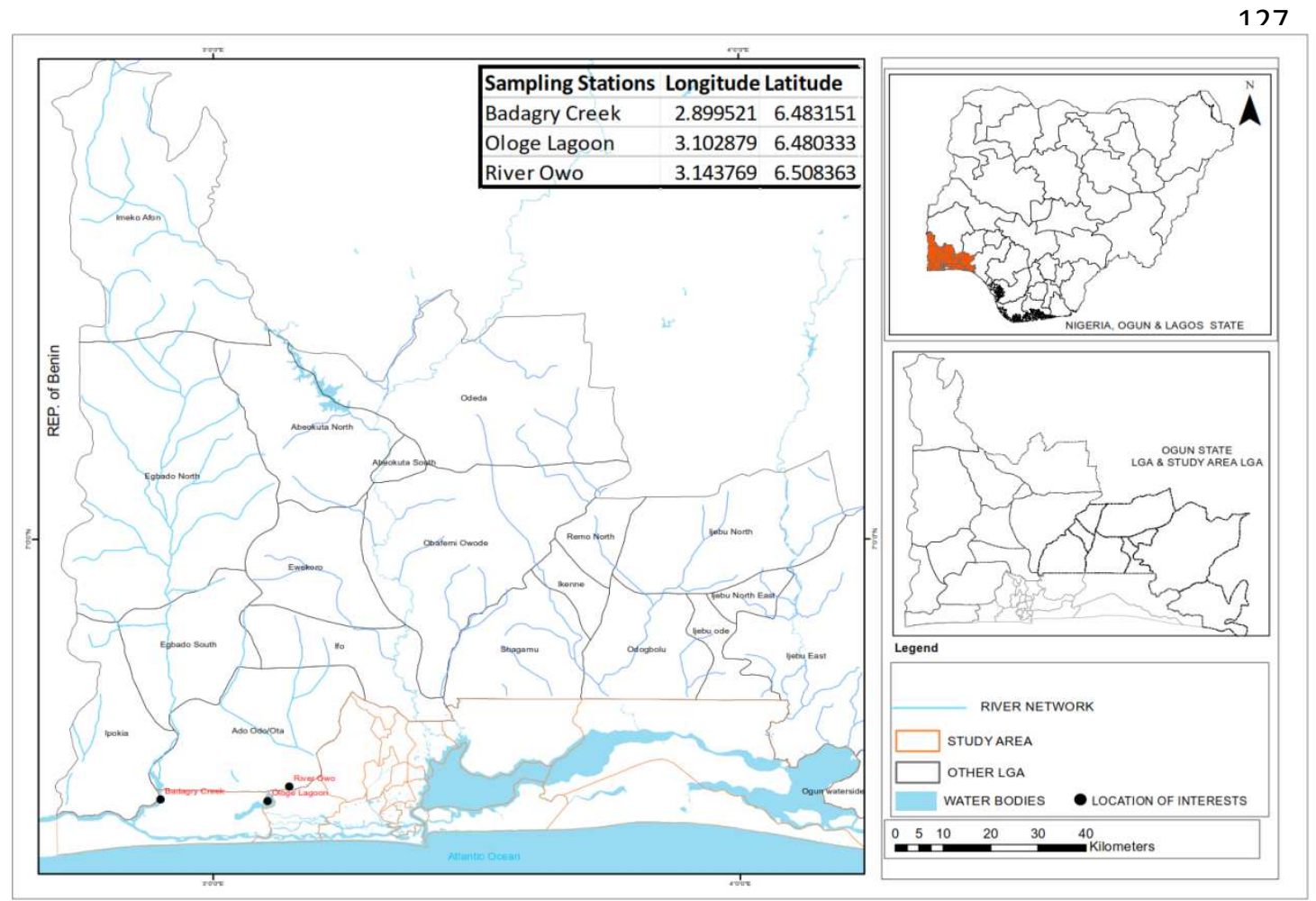

Figure 1: Map of study area showing sampling sites (River Owo, Ologe Lagoon and Badagry Creek)

\subsubsection{Length-weight analysis and condition factor}

A total of 1,367 fish samples (Badagry Creek = 536; River Owo = 277; Ologe Lagoon = 554) belonging to 15 families (claroteidae, cichlidae, clupeidae. haemulidae, cynoglossidae, mugilidae, lutjanidae, carangidae, clariidae, uranoscopidae, channidae, anabantidae, gymnarchidae, mormyridae, gobiidae) were collected randomly from the three study sites from January December, 2018. Artisanal fishermen from villages around the study sites deploy surface and bottom-set gillnets, cast-nets, drift-nets and beach-seines for their catches. Fish samples were immediately preserved in $10 \%$ formalin and taken to the laboratory for identification using the keys provided by Schneider (1992) and Leveque et al. (1990). The total weight (g) of each fish was measured on a top loading Metler balance after bolt drying while the total body lengths (TL) were measured to the nearest centimeter $(\mathrm{cm})$ with a ruler. Parameters of the length-weight relationship of identified fish species were estimated using the equation: 
163 Where $\mathrm{W}=$ weight $(\mathrm{g}), \mathrm{L}=$ length $(\mathrm{cm}), \mathrm{a}(\mathrm{y}$-intercept $)=$ the initial growth coefficient, and $\mathrm{b}$ 164 (slope $)=$ the growth coefficient.

165 The values of constants a and b were estimated after logarithmic transformation of Eq. (1) using 166 least square linear regression (Zar, 1984) to give:

167

168

169

170

171

172

173

174

175

176

177

178

179

180

181

182

183

184

185

186

187

188

189

190

191

192

193

194

195

196

197

198

199

200

201

202

203

204

$\log \mathrm{W}=\log \mathrm{a}+\mathrm{b} \log \mathrm{L}$

Before the regression analysis of $\log \mathrm{W}$ on $\log \mathrm{L}, \log -\log$ plots of length and weight values were performed for visual inspection of outliers (Froese, 2006). Extreme outliers which could be attributed to data error were not used for the analyses. The $95 \%$ confidence interval (CI) of b was calculated using the equation:

$\mathrm{CI}=\mathrm{b} \pm(1.96 \times \mathrm{SE})$

Where SE is the standard error of $b$.

In order to confirm whether $b$ values obtained in the linear regressions were significantly different from the isometric value of $\pm 95 \% \mathrm{CI}$ of $\mathrm{b}$ at $\alpha=0.05$, $\mathrm{t}$-test was applied as expressed by the equation according to Sokal and Rohlf (1987):

$\mathrm{t}_{\mathrm{s}}=(\mathrm{b}-3) / \mathrm{SE}$

where $t_{s}$ is the $t$-test value, $b=$ slope and $S E=$ the standard error of the slope $(b)$.

All the statistical analyses were considered at significance level of 5\% $(\mathrm{p}<0.05)$. The condition factor was computed by the formula:

Condition Factor $(\mathrm{K})=100 \mathrm{~W} / \mathrm{L}^{3} \quad($ Pauly, 1983)

\subsubsection{Heavy Metal Analyses}

2.2.3.1 Collections of samples: Water samples were collected in $0.5 \mathrm{~L}$ plastic bottles. After collection, samples were properly covered and were refrigerated at $4^{\circ} \mathrm{C}$ to inactivate microbes and thus preserve the integrity of the samples in the Ecotoxicology and Ecosystem Modelling laboratory, Department of Fisheries, Faculty of Science, Lagos State University, Ojo, Lagos State, Nigeria. Immediately after collection, $5 \mathrm{ml}$ nitric acid (Analar grade, Merck, Darmstadt, Germany) was added to the water samples to minimize metal adsorption onto the inner sides of the sample bottles (APHA 1985).

Grab samples of sediment were collected with a 2-inch diameter steel pipe pressed through the water column to obtain a sediment core of $60 \mathrm{~cm}$ below the water surface (Ali and Fishar, 2005). The sediment was emptied into polythene bags previously treated with $10 \%$ nitric acid (Analar grade, Merck, Darmstadt, Germany) and sealed (Ndimele et al, 2017). About three to five 
composite samples were collected from each station on each day of sampling. All samples were stored in a deep freezer at $-10^{\circ} \mathrm{C}$. Coptodon zillii were caught monthly from each site with fishing gears like gill net, cast net and hook and identified using the identification key by Schneider, 1992 and Leveque et al. (1990). The total lengths and body weights of the fish were determined using meter rule and digital scale (OHAUS Scout pro, USA) respectively. The fish were preserved immediately after capture in a refrigerator $\left(-10^{\circ} \mathrm{C}\right)$. The mean weight of the fish was $234.48 \pm 42.11$ $\mathrm{g}$ to the nearest $0.1 \mathrm{~g}$ while the mean total length was $15.19 \pm 4.08 \mathrm{~cm}$ to the nearest millimeter. About 4 - 5 C. zillii were collected from each site on the sampling days, giving a total of $48-60$ fish samples obtained from each sampling site. Triplicate samples of water, sediment, and C. zillii were collected from each sampling station on every sampling day.

\subsubsection{Sample treatment}

Sample treatment

Frozen samples of sediment, water, and fish (Coptodon zillii) were allowed to melt at room temperature $\left(\sim 27^{\circ} \mathrm{C}\right)$. There was no further treatment on water samples but they were mixed vigorously before aspiration into the flames of an atomic absorption spectrophotometer. Sediment samples were oven-dried to constant weight at $105 \pm 20^{\circ} \mathrm{C}$, and sieved through a $2 \mathrm{~mm}$ mesh screen to remove plant materials, stones, and other unwanted particles (Varol, 2011). In order to obtain fine sediment particles used for analyses, the sediment samples were grinded in an agate mortar and passed through a 500- $\mu \mathrm{m}$ stainless steel sieve after which they were stored in pre-washed glass bottles (Oliva et al. 2012). The level of heavy metal in sediment was determined by digesting 0.25 g sediment in a Teflon vessel with $12 \mathrm{ml} \mathrm{HNO}_{3}$ (65\% Suprapur, Merck, Darmstadt, Germany)/HCl (37\% Suprapur, Merck, Darmstadt, Germany) in the ratio 3:1. A microwave oven (MARSX-Press, CEM) (USEPA, 2007) was used for the digestion. The digested samples were filtered, adjusted to appropriate volumes with Milli-Q deionized water (Millipore, USA), and stored until heavy metal analysis. The fish samples were digested by drying them at $105 \pm 5^{\circ} \mathrm{C}$ and pulverizing in a mortar. The powdered fish sample $(0.5 \mathrm{~g})$ was added to a mixture of $6 \mathrm{ml} \mathrm{HNO}$ (65\% Suprapur, Merck, Darmstadt, Germany) and $2 \mathrm{ml} \mathrm{H}_{2} \mathrm{O}_{2}$ (30\% Suprapur grade, Merck, Darmstadt, Germany) (Sary and Mohammadi, 2012). High-performance microwave (MLS-1200 MEGA, MLS GmbH, Germany) was used for the digestion of the fish samples. The conditions of the microwave were set according to the description in Mendil et al. (2005): 2 min at $250 \mathrm{~W}, 2 \mathrm{~min}$ at $0 \mathrm{~W}, 6 \mathrm{~min}$ at $250 \mathrm{~W}, 5 \mathrm{~min}$ at $400 \mathrm{~W}$, and $8 \mathrm{~min}$ at 550W and then vented for $8 \mathrm{~min}$. The samples were allowed to cool after which, they were transferred to $20 \mathrm{ml}$ volumetric flasks, made up to the mark with distilled water and stored until metal analysis. The concentrations of metals in procedural blanks were negligible.

2.2.3.3 Heavy Metal Determination: Six metals (zinc, lead, copper, iron, arsenic, and cadmium) were analysed in water, sediment and fish. The samples were filtered with a nitrocellulose membrane filter $(0.45 \mu \mathrm{m})$ before analysis. In the laboratory, sample blanks were prepared in the same way as the field samples (Maceda-Veiga et al., 2012; Türkmen et al., 2009). The samples were analysed three times for the six heavy metals by Inductively Coupled Plasma-Atomic Emission Spectrometer (ICP-AES) Varian Liberty Series II (operating conditions: RF power, $1000 \mathrm{~W}$; plasma gas flow, 12L/min; torch configuration, radial; nebulizer, V-groove; spray chamber, double-pass cylindrical; detector, photomultiplier). Standard solutions were prepared by 
272

273

274

275

276 278

279

\subsubsection{Fish Diversity Indices}

Simpson's dominance index is based on this formula:

Where $n_{i}=$ the number of individuals in the ith species;

$\mathrm{N}=$ the total number of individuals

$\mathrm{S}=$ the total number of species

Therefore, Simpson's index of diversity $=1-\mathrm{D}$

Simpson's reciprocal index $=1 / \mathrm{D}$

Shannon's diversity index is based on the equation below:

Where $\mathrm{P}_{\mathrm{i}}=\mathrm{n}_{\mathrm{i}} / \mathrm{N}$

277 Shannon's diversity index $\left(\mathrm{H}^{1}\right)=-\sum_{i=1}^{S} \mathrm{P}_{\mathrm{i}}$. Loge $\mathrm{P}_{\mathrm{i}} \quad$ (Shannon and Wiener, 1949)

diluting stock solutions (Merck, multi-element standard) and the latter were used for system calibration and control of analytical accuracy. All samples were run in batches composed of two spiked samples, a standard calibration curve, one duplicate and blanks (Türkmen et al., 2008). Method accuracy and precision were validated by analyzing $(n=6)$ dogfish muscle (DORM-2, National Research Council, Canada) as a certified reference material. The recovery rate (\% mean recovery \pm S.E.) was also analyzed $(\mathrm{n}=6)$ (Zrnčić et al., 2013). The correlation between the analytical and certified values was strong. The recovery was $97.2 \pm 2.3 \%$ for $\mathrm{Cu}, 96.5 \pm 3.8 \%$ for $\mathrm{Fe}$, $97.6 \pm 3.6 \%$ for $\mathrm{Pb}, 98.6 \pm 2.8 \%$ for $\mathrm{Ar}, 97.4 \pm 3.3 \%$ for $\mathrm{Cd}$ and $97.8 \pm 3.5 \%$ for $\mathrm{Zn}$. The analytical procedure had good precision, which was calculated as the relative standard deviation (RSD) and the values obtained ranged from 6 and 9\%. The analysis of standard solution had precision value that is better than $5 \%$. Each of the analyses was repeated twice, and the results obtained were reported as the average. Metal contents were expressed as $\mathrm{mg} / \mathrm{kg}$ dry weight.

The fish assemblage structure was estimated for each site and it included: Simpson's dominance index (D), Simpson index of diversity (1-D), Simpson's reciprocal index (1/D), Shannon diversity index $\left(\mathrm{H}^{\prime}\right)$, evenness index $\left(\mathrm{E}^{1}\right)$, Brillouin (HB), Menhinick's Index of Species Abundance, Margalef's index of species richness (S), equitability (J), fisher alpha and Berger-parker (d).

Simpson's dominance index $(D)=\sum_{i=1}^{S} \frac{n_{i}\left(n_{i}-1\right)}{N(N-1)} \quad$ (Simpson, 1949)

Simpson's indices of diversity (1-D) and reciprocal (1/D) are obtained from Simpson's dominance index by subtracting dominance index from 1 and dividing 1 by dominance index respectively. 
282

283

284

285

286

287

288

289

290

291

292

293

294

295

296

297

298

299

300

301

302

303

304

305

306

307

308

309

310

311

312

313

314

315
Evenness index $(\mathrm{E})=\frac{\mathrm{H}^{1}}{\operatorname{LogeS}}$

(Pielou, 1966)

Brillouin's index $(\mathrm{H})$ is defined as:

$$
H=\frac{1}{n} \log \frac{n !}{\prod_{i=1}^{k} n_{i} !}=\frac{\log n !-\sum_{i=1}^{k} \log n_{i} !}{n}
$$

where $n_{i}$ is the number of observations from the sample in the $i^{\text {th }}$ of $k$ (non-empty) categories and $n$ is the sample size.

Fish species richness in the sites was evaluated using two indices; menhinick's and margalef's indices.

Menhinick's Index of Species Abundance $=\mathrm{S} / \sqrt{ } \mathrm{N}$

Margalef's Index of Species Abundance $=\mathrm{S}-1$ / LogeN

Where $\mathrm{S}$ is the total number of species and $\mathrm{N}$ is the total number of individuals.

Fisher's alpha is a diversity index, defined implicitly by the formula:

$\mathrm{S}=\mathrm{a}^{*} \log \mathrm{e}(1+\mathrm{n} / \mathrm{a})$

where $S$ is number of species, $n$ is number of individuals and $a$ is the Fisher's alpha.

The Berger-Parker index equals the maximum $p_{i}$ value in the dataset or sampling station, i.e. the proportional abundance of the most abundant species.

Where $\mathrm{p}_{\mathrm{i}}=\mathrm{n}_{\mathrm{i}} / \mathrm{N}$ as has been earlier expressed.

\subsubsection{Sediment pollution indices}

2.2.5.1 Enrichment factor: Enrichment Factor (EF) was calculated following the method of Adaikpoh (2013). The EF normalizes the level of the measured potentially harmful elements with respect to a reference metal such as $\mathrm{Fe}, \mathrm{Al}$ or $\mathrm{Zn}$ (Mediolla et al, 2008). In this study, Fe was used as the reference metal or normalizer because of its abundance in Nigerian soils and natural sources (98\%) vastly dominate its input (Ndimele and Kumolu-Johnson, 2012; Nasir and Harikumar, 2011). The crustal abundance data of Bowen (1979) were used for all EF values.

The EF of heavy metal in sediment was calculated as: 
317 where $\mathrm{C}_{\text {metal }}$ and $\mathrm{C}_{\text {normalizer }}$ are concentrations of heavy metal and normalizer $(\mathrm{Fe})$ in the sediment 318 and in the earth's crust. The EF value is used to distinguish the magnitude of contamination resulting from either the natural or anthropogenic influence (Nasir and Harikumar, 2011).

2.2.5.2 Geoaccumulation index (Igeo): Igeo was calculated for different metals according to the formula introduced by Muller (1969):

where $C_{n}$ is the measured concentration of the metals in the sediment samples and $B_{n}$ is the geochemical background concentrations in soils derived from rocks of average shale composition (Muller, 1969). The factor 1.5 was introduced to minimise the possible variation of the background values attributable to lithological variations.

2.2.5.3 Contamination factor: The Contamination Factor (CF) was calculated according to Hakanson (1980):

$\mathrm{CF}=\mathrm{C}_{\mathrm{m}}($ sample $) / \mathrm{C}_{\mathrm{m}}$ (background)

where, $\mathrm{C}_{\mathrm{m}}$ (sample) is the concentration of metals in the sediments of the sampling sites and $\mathrm{C}_{\mathrm{m}}$ (background) is the concentration of metals in a control or background sediment sample. The CF is defined according to 4 categories: Low contamination $(\mathrm{CF}<1)$, moderate contamination $(1 \leq \mathrm{CF}<3)$, considerable contamination $(3 \leq \mathrm{CF}<6)$, and very high contamination $(\mathrm{CF}>6)$ (Wang et al, 2006).

2.2.5.4 Pollution load index (PLI) is given by the equation;

$\mathrm{PLI}=\left(\mathrm{CF}_{1} \times \mathrm{CF}_{2} \times \mathrm{CF}_{3} \times \ldots \mathrm{CF}_{\mathrm{n}}\right)^{1 / \mathrm{n}} \quad$ (Tomlinson et al, 1980)

where $\mathrm{CF}$ is the contamination factor, $\mathrm{n}$ is the number of metals studied.

2.2.5.5 The modified degree of contamination $(m C d)$ is a generalized form of the Håkanson (1980) equation proposed by Abrahim (2005) for the calculation of the combined contaminations of a given study site:

$\mathrm{mCd}=\frac{\sum_{i=1}^{n} \mathrm{CF}_{\mathrm{i}}}{\mathrm{n}}$

The following classification of modified degree of contamination in sediments has been proposed: very low contamination $(\mathrm{mCd}<1.5)$; low degree of contamination $(1.5 \leq \mathrm{mCd}<2)$; moderate degree of contamination $(2 \leq \mathrm{mCd}<4)$; high degree of contamination $(4 \leq \mathrm{mCd}<8)$; very high degree of contamination $(8 \leq \mathrm{mCd}<16)$; extremely high degree of contamination $(16 \leq \mathrm{mCd}<32)$ and ultra high degree of contamination $(\mathrm{mCd} \geq 32)$. 
$377 \quad E_{r}^{i}=T_{r}^{i} C_{f}^{i}$

$$
\begin{aligned}
& \mathrm{R}_{1}=\sum \mathrm{E}_{\mathrm{r}}^{\mathrm{i}} \\
& \mathrm{E}_{\mathrm{r}}^{\mathrm{i}}=\mathrm{T}_{\mathrm{r}}^{\mathrm{i}} \mathrm{C}_{\mathrm{f}}^{\mathrm{i}} \\
& \mathrm{C}_{\mathrm{f}}^{\mathrm{i}}=\mathrm{C}_{0}^{\mathrm{i}} / \mathrm{C}_{\mathrm{n}}^{\mathrm{i}}
\end{aligned}
$$

\subsubsection{Ecotoxicology of heavy metals in sediment and potential ecological risks}

Two sets of standard quality guidelines (SQGs) developed for aquatic environments were applied in this study to evaluate the ecotoxicological potentials of heavy metals in sediments. The SQGs are the effect range-low (ERL)/effect range-median (ERM); and the threshold effect level (TEL)/probable effect level (PEL) values (MacDonald et al, 2000; Long and MacDonald, 1998). The low range values (ERLs/TELs) are concentrations below which adverse effects on animals living in sediment would infrequently be observed. In contrast, the ERMs and PELs are concentrations above which adverse effects are likely to occur (Long and MacDonald, 1998). The comparison method used in this study is the mean quotients (m-PEL-Q, m-ERM-Q) calculated from PEL and ERM values according to Long et al (1995) as follows:

$$
\mathrm{m}-\mathrm{PEL}-\mathrm{Q}=\left(\sum_{i=1}^{n} \frac{\mathrm{C}_{\mathrm{i}}}{\mathrm{PEL}_{\mathrm{i}}}\right) / \mathrm{n}
$$

$$
\text { m-ERM-Q }=\left(\sum_{i=1}^{n} \frac{C_{i}}{\operatorname{ERM}_{\mathrm{i}}}\right) / \mathrm{n}
$$

The potential ecological risk posed by the metals was assessed by the method described by Håkanson (1980). The formulae are:

where $\mathrm{R}_{1}$ is the sum of all risk factors for all metals in sediments, $\mathrm{E}_{\mathrm{r}}^{\mathrm{i}}$ is the monomial potential ecological risk factor, $\mathrm{T}_{r}^{\mathrm{i}}$ is the toxic-response factor for a given metal/substance, $\mathrm{C}_{r}{ }_{r}$ is the contamination factor, $\mathrm{C}_{0}{ }_{0}$ is the concentration of metals in the sediment samples, and $\mathrm{C}_{n}^{\mathrm{i}}$ is a reference/background value for metals.

\subsubsection{Health risk assessment of heavy metals}

The assessment of the risks associated with the consumption of a fish (Coptodon zillii) from the sampling stations was done with two indices; estimated dietary intake (EDI) and target hazard quotients (THQ). The daily intake of contaminant depends on factors like the concentration of the contaminant in food, rate of food consumption and body weight of the food consumer (Zhao et al, 2012; Wang et al, 2005).

$\mathrm{EDI}=C_{\text {metal }} \times$ DNI $x C_{f} / B_{w}$ 
where $C_{\text {metal }}$ is the concentration $\left(\mathrm{mg} \mathrm{kg}^{-1}\right)$ of the heavy metals in the muscle tissue of $C$. zillii, DNI is the daily nutritional intake in $\left(\mathrm{g} \mathrm{day}^{-1}\right)$, and $C_{f}$ is the factor for conversion of fresh fish tissues to dry constant weight. The average moisture content in $C$. zillii was $70.56 \%$ and the $C_{f}(0.2944)$ was calculated using the equation reported by Abubakar et al (2015). The average body weight for adults in Nigeria is $70 \mathrm{~kg}$. The daily nutritional intake of $C$. zillii was evaluated by adopting the ingestion rate for Nigeria based on 2011 estimate by FAO. The DNI for adults is $62.60 \mathrm{~g}$ capita-1 day-1 (FAO, 2015).

Chen et al (2002) model for estimating target hazard quotient was used in this study:

$\mathrm{THQ}=\frac{\text { EFr } \times \text { EDtot } \times \text { FIR } \times \mathrm{C} \times 10^{-3}}{\text { RfDo } \times \text { Bw } \times A T n}$

where THQ is the target hazard quotient; EFr is exposure frequency (365 days/year); EDtot is the exposure duration (55.2 years, average lifetime of Nigerians); FIR is the food ingestion rate (g/day); $\mathrm{C}$ is the heavy metal concentration in fish $(\mathrm{mg} / \mathrm{g})$; RfDo is the oral reference dose $(\mathrm{mg} / \mathrm{kg} /$ day $) ; \mathrm{Bw}$ is the average adult body weight of Nigerians $(60.75 \mathrm{~kg})$; and ATn is the average exposure time for non-carcinogens (365 days/year x number of exposure years, assuming 55.2 years).

Hallenbeck (1993) reported that multiple exposure to pollutants can results in additive and/or interactive effects. In this study, the total THQ is calculated as the arithmetic sum of the individual metal THQ values:

Total THQ $=$ THQ (toxicant 1$)+$ THQ (toxicant 2$)+\ldots+$ THQ (toxicant $n)$

2.5 Statistical Analysis: One way analysis of variance (ANOVA) was used to assess significant differences among the sampling stations. The comparison of mean using the Least Significant difference (LSD) test was calculated for $p$-values. A value of $(\mathrm{p}<0.05)$ was considered significant.

\subsection{RESULTS}

3.1 Physicochemical analysis of water samples

The summary of data on the physicochemical parameters of water in the sampling stations is presented in table 1 . There were no significant difference $(p>0.05)$ in the temperature, salinity, total suspended solids (TSS), dissolved oxygen (DO), and chlorophyll-a among the sampling stations. However, $\mathrm{pH}$, turbidity, conductivity, total dissolved solids (TDS), total solids (TS), biochemical oxygen demand (BOD), carbon dioxide, total alkalinity and ammonia $\left(\mathrm{NH}_{3}\right)$ varied significantly $(\mathrm{p}<0.05)$ among the sampling stations. The highest values in turbidity $(18.90 \pm 3.3$ NTU), conductivity $(512.85 \pm 233.41 \mu \mathrm{S} / \mathrm{cm})$, total dissolved solids $(298.70 \pm 124.78 \mathrm{mg} / \mathrm{L})$, total solids $(338.47 \pm 122.84 \mathrm{mg} / \mathrm{L})$, biochemical oxygen demand $(29.50 \pm 9.89 \mathrm{mg} / \mathrm{L})$ and ammonia $(0.18 \pm 0.03 \mathrm{mg} / \mathrm{L})$ were recorded in Badagry Creek while the lowest values in these parameters \{turbidity $(10.54 \pm 1.44 \mathrm{NTU})$, conductivity $(133.22 \pm 10.80 \mu \mathrm{S} / \mathrm{cm})$, total dissolved solids $(72.25 \pm 5.84 \mathrm{mg} / \mathrm{L})$, total solids $(93.33 \pm 5.56 \mathrm{mg} / \mathrm{L})$, biochemical oxygen demand $(7.35 \pm 1.18$ $\mathrm{mg} / \mathrm{L})$ and ammonia $(0.04 \pm 0.01 \mathrm{mg} / \mathrm{L})\}$ were recorded in River Owo. River Owo had the highest values in carbon dioxide $(81.67 \pm 16.64 \mathrm{mg} / \mathrm{L})$ and total alkalinity $(80.38 \pm 5.95 \mathrm{mg} / \mathrm{L})$ but their lowest values were obtained in Ologe Lagoon $(56.85 \pm 5.91 \mathrm{mg} / \mathrm{L})$ and Badagry Creek $(48.12 \pm 3.55$ 
$441 \mathrm{mg} / \mathrm{L})$ respectively. The highest value for $\mathrm{pH}(6.48 \pm 0.18)$ was recorded in Ologe Lagoon and the 442 lowest value (5.43 \pm 0.48$)$ in Badagry Creek.

\begin{tabular}{lcccc}
\hline PARAMETERS & $\begin{array}{c}\text { Badagry } \\
\text { Creek }\end{array}$ & $\begin{array}{c}\text { River } \\
\text { Owo }\end{array}$ & $\begin{array}{c}\text { Ologe } \\
\text { Lagoon }\end{array}$ & $\begin{array}{c}\text { WHO } \\
\text { Standard }\end{array}$ \\
\hline Temperature $\left({ }^{\mathrm{o}} \mathrm{C}\right)$ & $25.78 \pm 0.16^{\mathrm{a}}$ & $25.85 \pm 0.11^{\mathrm{a}}$ & $25.77 \pm 0.19^{\mathrm{a}}$ & $<40$ \\
$\mathrm{pH}$ & $5.43 \pm 0.48^{\mathrm{a}}$ & $6.38 \pm 0.25^{\mathrm{a}}$ & $6.48 \pm 0.18^{\mathrm{b}}$ & $5.5-9.0$ \\
Turbidity $(\mathrm{NTU})$ & $18.90 \pm 3.3^{\mathrm{a}}$ & $10.54 \pm 1.44^{\mathrm{b}}$ & $15.92 \pm 1.70^{\mathrm{a}}$ & 5.0 \\
Salinity $(\mathrm{ppt})$ & $0.29 \pm 0.12^{\mathrm{a}}$ & $0.10 \pm 0.01^{\mathrm{a}}$ & $0.23 \pm 0.04^{\mathrm{a}}$ & $\mathrm{NS}$ \\
Conductivity $(\mu \mathrm{S} / \mathrm{cm})$ & $512.85 \pm 233.41^{\mathrm{a}}$ & $133.22 \pm 10.80^{\mathrm{b}}$ & $377.78 \pm 83.03^{\mathrm{ab}}$ & 250 \\
TDS $(\mathrm{mg} / \mathrm{l})$ & $298.70 \pm 124.78^{\mathrm{a}}$ & $72.25 \pm 5.84^{\mathrm{c}}$ & $210.52 \pm 45.32^{\mathrm{b}}$ & 2100 \\
TSS (mg/l) & $40.62 \pm 12.44^{\mathrm{a}}$ & $21.10 \pm 4.20^{\mathrm{a}}$ & $39.57 \pm 5.745^{\mathrm{a}}$ & 100 \\
Total Solids $(\mathrm{mg} / \mathrm{l})$ & $338.47 \pm 122.84^{\mathrm{a}}$ & $93.33 \pm 5.56^{\mathrm{b}}$ & $246.92 \pm 48.44^{\mathrm{a}}$ & 2200 \\
Dissolved oxygen $(\mathrm{mg} / \mathrm{l})$ & $4.52 \pm 0.38^{\mathrm{a}}$ & $4.78 \pm 0.13^{\mathrm{a}}$ & $4.57 \pm 0.34^{\mathrm{a}}$ & $>2.0$ \\
BOD $(\mathrm{mg} / \mathrm{l})$ & $29.50 \pm 9.89^{\mathrm{a}}$ & $7.35 \pm 1.18^{\mathrm{b}}$ & $26.00 \pm 14.05^{\mathrm{a}}$ & 50 \\
Carbon dioxide $(\mathrm{mg} / \mathrm{l})$ & $57.17 \pm 36.30^{\mathrm{a}}$ & $81.67 \pm 16.64^{\mathrm{b}}$ & $56.85 \pm 5.91^{\mathrm{a}}$ & - \\
Total alkalinity $(\mathrm{mg} / \mathrm{l})$ & $48.12 \pm 3.55^{\mathrm{a}}$ & $80.38 \pm 5.95^{\mathrm{b}}$ & $56.85 \pm 5.91^{\mathrm{a}}$ & 120 \\
Ammonia $(\mathrm{mg} / \mathrm{l})$ & $0.18 \pm 0.03^{\mathrm{a}}$ & $0.04 \pm 0.01^{\mathrm{b}}$ & $0.15 \pm 0.04^{\mathrm{a}}$ & - \\
Chlorophyll-a $(\mu / \mathrm{L})$ & $7.60 \pm 0.41^{\mathrm{a}}$ & $7.08 \pm 0.41^{\mathrm{a}}$ & $8.83 \pm 0.87^{\mathrm{a}}$ & $\mathrm{NS}$ \\
\hline
\end{tabular}

443

444

445

446

447

448

449

450

451

452

453

454

455

456

457

458

459

460

461

462

463

464

465

466

\section{Table 1: Physicochemical parameters of water in the sampling stations}

BOD $=$ biochemical oxygen demand $;$ TDS $=$ total dissolved solids $;$ TSS $=$ total suspended solids

Values in the same row and with the same superscript are not significantly $(p>0.05)$ different. All values are expressed as mean \pm S.E 
467 Table 2: Length-weighted regression analysis of fish species in Badagry Creek, River Owo and 468 Ologe Lagoon

\begin{tabular}{|c|c|c|c|c|c|c|c|c|}
\hline Source & Fish species & $\mathbf{N}$ & $\mathbf{a}$ & b & $\mathbf{K}$ & $95 \% \mathrm{CI}$ for $b$ & $\mathbf{r}$ & $\begin{array}{l}\text { Growth } \\
\text { Pattern }\end{array}$ \\
\hline \multirow{13}{*}{$\begin{array}{l}\text { Badagry } \\
\text { Creek }\end{array}$} & Chrysichthys nigrodigitatus & 96 & 0.015 & 2.901 & 0.87 & $2.751-3.051$ & 0.96 & - \\
\hline & Coptodon zillii & 58 & 0.019 & 3.081 & 4.51 & $2.867-3.295$ & 0.92 & 1 \\
\hline & Sardinella maderensis & 21 & 0.024 & 2.716 & 1.62 & $2.381-3.051$ & 0.95 & - \\
\hline & Pellonula leonensis & 15 & 0.004 & 3.183 & 1.73 & $3.164-3.202$ & 0.96 & + \\
\hline & Pomadasys jubelini & 22 & 0.018 & 2.875 & 1.21 & $2.652-3.098$ & 0.97 & - \\
\hline & Sarotherodon melanotheron & 18 & 0.023 & 2.776 & 2.18 & $2.522-3.030$ & 0.98 & - \\
\hline & Cynoglossus senegalensis & 46 & 0.006 & 2.815 & 0.94 & $2.806-2.824$ & 0.95 & - \\
\hline & Mugil cephalus & 41 & 0.008 & 3.042 & 0.84 & $3.033-3.052$ & 0.96 & 1 \\
\hline & Lutjanus agennes & 19 & 0.007 & 3.058 & 3.24 & $2.553-3.563$ & 0.93 & 1 \\
\hline & Caranx hippos & 18 & 0.027 & 2.844 & 2.12 & $2.664-3.024$ & 0.96 & - \\
\hline & Ethmalosa fimbriata & 72 & 0.008 & 3.088 & 1.14 & 3.083- 3.093 & 0.95 & 1 \\
\hline & Clarias gariepinus & 29 & 0.016 & 2.901 & 0.92 & $2.488-3.314$ & 0.98 & - \\
\hline & Uranoscopus polli & 81 & 0.018 & 2.914 & 3.13 & $2.704-3.124$ & 0.97 & - \\
\hline River & Chrysichthys nigrodigitatus & 33 & 0.018 & 2.941 & 2.62 & $2.932-2.950$ & 0.85 & - \\
\hline \multirow[t]{7}{*}{ Owo } & Coptodon zillii & 43 & 0.022 & 2.824 & 4.43 & $2.644-3.004$ & 0.92 & - \\
\hline & Sarotherodon melanotheron & 31 & 0.028 & 2.813 & 4.18 & $2.623-3.003$ & 0.88 & - \\
\hline & Oreochromis niloticus & 60 & 0.018 & 2.941 & 3.92 & $2.916-2.966$ & 0.80 & - \\
\hline & Parachanna obscura & 24 & -1.893 & 2.905 & 2.13 & $2.885-2.925$ & 0.81 & - \\
\hline & Ctenopoma petherici & 27 & 0.036 & 2.855 & 2.08 & $2.735-2.975$ & 0.79 & - \\
\hline & Clarias gariepinus & 38 & 0.014 & 2.993 & 1.26 & $2.843-3.143$ & 0.94 & 1 \\
\hline & Gymnarchus niloticus & 21 & -0.950 & 2.348 & 1.12 & $2.168-2.528$ & 0.76 & - \\
\hline Ologe & Chrysichthys nigrodigitatus & 78 & 0.013 & 2.962 & 2.11 & $2.955-2.969$ & 0.95 & - \\
\hline \multirow[t]{10}{*}{ Lagoon } & Coptodon zillii & 52 & 0.024 & 2.716 & 3.52 & $2.704-2.728$ & 0.81 & - \\
\hline & Sardinella maderensis & 41 & 0.030 & 2.543 & 3.95 & $2.403-2.728$ & 0.87 & - \\
\hline & Cynothrissa mento & 48 & 0.023 & 2.478 & 6.26 & $2.438-2.518$ & 0.80 & - \\
\hline & Hyperopisus bebe & 65 & 0.021 & 2.684 & 2.61 & $2.679-2.689$ & 0.75 & - \\
\hline & Sarotherodon melanotheron & 45 & 0.032 & 2.605 & 2.32 & $2.575-2.635$ & 0.80 & - \\
\hline & Oreochromis niloticus & 75 & 0.021 & 2.812 & 2.78 & $2.803-2.821$ & 0.85 & - \\
\hline & Mugil cephalus & 24 & 0.017 & 2.868 & 2.63 & $2.843-2.893$ & 0.92 & - \\
\hline & Bathygobius soporator & 20 & 0.020 & 2.651 & 4.86 & $2.636-2.666$ & 0.83 & - \\
\hline & Liza falcipinnis & 86 & 0.018 & 2.996 & 1.54 & $2.980-3.012$ & 0.96 & I \\
\hline & Ethmalosa fimbriata & 20 & 0.034 & 2.835 & 2.12 & $2.817-2.853$ & 0.87 & - \\
\hline
\end{tabular}
correlation coefficient, $-=$ negative allometric; $+=$ positive allometric; $\mathrm{I}=$ isometric.

471

472

473 


\subsection{Length-weight relationship and condition factor}

A total of 1,367 individuals belonging to 21 genera were analysed in this study. In Badagry Creek, 13 genera were encountered while River Owo and Ologe Lagoon recorded 8 and 11 genera respectively. Three species were common to the 3 sampling stations; Chrysichthys nigrodigitatus, Coptodon zillii and Sarotherodon melanotheron. The species, number of specimens, length-weight relationship parameters a and $b$, condition factor $(\mathrm{K}), 95 \%$ confidence interval for $b$, correlation coefficient (r), and growth type (allometric or isometric) are presented in Table 2. The sample size varies from 18 (Sarotherodon melanotheron, Caranx hippos) to 96 (Chrysichthys nigrodigitatus) in Badagry Creek, 21 (Gymnarchus niloticus) to 60 (Oreochromis niloticus) in River Owo and 24 (Mugil cephalus) to 86 (Liza falcipinnis) in Ologe Lagoon. The value of b ranges from 2.716 (Sardinella maderensis) to 3.183 (Pellonula leonensis), 2.813 (Sarotherodon melanotheron) to 2.993 (Clarias gariepinus) and 2.478 (Cynothrissa mento) to 2.996 (Liza falcipinnis) in Badagry Creek, River Owo and Ologe Lagoon respectively. The correlation coefficient (r) varies from 0.92 (Coptodon zillii) to 0.98 (Sarotherodon melanotheron, Clarias gariepinus) in Badagry Creek, 0.76 (Gymnarchus niloticus) to 0.94 (Clarias gariepinus) in River Owo and 0.75 (Hyperopisus bebe) to 0.96 (Liza falcipinnis) in Ologe Lagoon. Most of the growth pattern in River Owo and Ologe Lagoon were negatively allometric except Clarias gariepinus that had isometric growth in River Owo and Liza falcipinnis that also had isometric growth in Ologe Lagoon. All the growth patterns were represented in Badagry Creek but most of them were negatively allometric as it occurred in the other two sampling stations. Only Pellonula leonensis had positive allometric growth while Coptodon zillii, Mugil cephalus, Lutjanus agennes and Ethmalosa fimbriata recorded isometric growth type. In Badagry Creek, the condition factor varied from 0.84 in M. cephalus to 4.51 in $C$. zillii. Coptodon zillii also had the highest condition factor (4.43) in River Owo but the lowest (1.12) was recorded in G. niloticus. The lowest (1.54) and highest (4.86) condition factor values in Ologe Lagoon were recorded in L. falcinnis and B. soporator respectively.

\subsection{Ecological indices of the sampling stations}

The ecological indices of the three sampling stations are presented in Table 3. Badagry Creek and Ologe Lagoon had the same Simpson's dominance index (D) (0.11) and Simpson's index of diversity (0.89), which is lower than the values recorded in River Owo (Simpson's dominance index $=0.14$; Simpson's index of diversity $=0.86$ ). About 5 diversity indices followed the same trend; the lowest values (Simpson's reciprocal index $=7.18$, Shannon's diversity index $=2.03$, Brillouin $=1.96$, Margalef's index of species abundance $=1.25$ and Fisher Alpha $=1.54$ ) were obtained in River Owo while the highest values (Simpson's reciprocal index $=9.23$, Shannon's diversity index $=2.37$, Brillouin $=2.32$, Margalef's index of species abundance $=1.91$ and Fisher Alpha $=2.40$ ) occurred in Badagry Creek. Two parameters followed the exact opposite trend of the five previous variables. The lowest values (evenness $=0.83$, equitability $=0.93$ ) were recorded in Badagry Creek while the highest values (evenness $=0.95$, equitability $=0.97$ ) were found in River Owo. The lowest values for Menhinick's index of species richness (0.47) and Berger-Parker 
514 (0.16) occurred in Ologe Lagoon while the highest value of the former was found in Badagry Creek

515 (0.56) and the latter in River Owo (0.22).

516

517

518 Table 3: Diversity Indices of fish species from Badagry Creek, River Owo and Ologe Lagoon

\begin{tabular}{llll}
\hline Diversity Indices & Badagry Creek & River Owo & Ologe Lagoon \\
\hline Simpson's Dominance Index (D) & 0.11 & 0.14 & 0.11 \\
Simpson's Index of Diversity (1-D) & 0.89 & 0.86 & 0.89 \\
Simpson's Reciprocal Index (1/D) & 9.23 & 7.18 & 9.18 \\
Shannon's Diversity Index (H ${ }^{1}$ ) & 2.37 & 2.03 & 2.29 \\
Evenness (E') & 0.83 & 0.95 & 0.90 \\
Brillouin (H) & 2.32 & 1.96 & 2.25 \\
Menhinick's Index of Species Abundance & 0.56 & 0.48 & 0.47 \\
Margalef's Index of Species Abundance & 1.91 & 1.25 & 1.58 \\
Equitability (J) & 0.93 & 0.97 & 0.96 \\
Fisher's Alpha (a) & 2.40 & 1.54 & 1.95 \\
Berger-Parker (d) & 0.18 & 0.22 & 0.16
\end{tabular}

519

520

521

522

523

524

525

526

527

528

529

530

531

532

533

\subsection{Sediment pollution indices}

The enrichment factors of the heavy metals in sediment of the sampling stations vary from $4.05 \times 10^{-}$ ${ }^{4}$ in $\mathrm{Cu}$ from River Owo to $8.65 \times 10^{-1}$ in Cd from Ologe Lagoon (Table 4). The geoaccumulation index (Igeo) of heavy metals in sediments of the sampling sites ranged from -12.14 to -0.38 (Table 4). Contamination factor (CF), pollution load index (PLI) and modified degree of contamination $(\mathrm{mCd})$ of metals in sediments of the 3 sampling stations are also shown in Table 4 . The contamination factors of $\mathrm{Fe}$ and $\mathrm{Cd}$ were higher than the other metals. The $\mathrm{CF}$ of Fe ranged from 0.36 in Ologe Lagoon to 1.15 in River Owo and 0.20 in River Owo to 0.38 in Badagry Creek for $\mathrm{Cd}$. For the other metals, the value varied from $3.33 \times 10^{-4}$ to $7.37 \times 10^{-3}$. The PLI was lowest $\left(6.97 \times 10^{-3}\right)$ in Ologe Lagoon and highest $\left(1.28 \times 10^{-2}\right)$ in River Owo. The modified degree of contamination followed the same trend as PLI; the lowest $(0.11)$ and highest $(0.23)$ were recorded in Ologe Lagoon and River Owo respectively. 
534 Table 4: Enrichment Factor, Geoaccumulation indices (Igeo), Contamination factor, pollution load index and modified degree of contamination of metals in sediments of Badagry Creek, River Owo and Ologe Lagoon

\begin{tabular}{|c|c|c|c|c|c|c|c|c|c|}
\hline \multirow{2}{*}{$\begin{array}{l}\text { Sampling } \\
\text { Station }\end{array}$} & & \multicolumn{6}{|c|}{ Heavy metal } & \multirow[t]{2}{*}{ PLI } & \multirow[t]{2}{*}{$\mathrm{mCd}$} \\
\hline & & $\mathrm{Zn}$ & $\mathrm{Pb}$ & $\mathrm{Cu}$ & $\mathrm{Fe}$ & As & $\mathrm{Cd}$ & & \\
\hline \multirow{3}{*}{$\begin{array}{l}\text { Badagry } \\
\text { Creek }\end{array}$} & $\overline{E F}$ & $8.25 \times 10^{-4}$ & $1.07 \times 10^{-2}$ & $1.02 \times 10^{-3}$ & - & $1.31 \times 10^{-3}$ & $6.54 \times 10^{-1}$ & & \\
\hline & Igeo & -11.6 & -7.9 & -11.29 & -1.36 & -10.93 & -1.97 & & \\
\hline & $\mathrm{CF}$ & $4.83 \times 10^{-4}$ & $6.28 \times 10^{-3}$ & $6.00 \times 10^{-4}$ & 0.59 & $7.69 \times 10^{-4}$ & 0.38 & $8.25 \times 10^{-3}$ & 0.16 \\
\hline \multirow{3}{*}{$\begin{array}{l}\text { River } \\
\text { Owo }\end{array}$} & $\mathrm{EF}$ & $4.46 \times 10^{-3}$ & $6.39 \times 10^{-3}$ & $4.05 \times 10^{-4}$ & - & $9.34 \times 10^{-4}$ & $1.71 \times 10^{-1}$ & & \\
\hline & Igeo & -8.19 & -7.67 & -11.65 & -0.38 & -10.44 & -2.93 & & \\
\hline & $\mathrm{CF}$ & $5.14 \times 10^{-3}$ & $7.37 \times 10^{-3}$ & $4.67 \times 10^{-4}$ & 1.15 & $1.08 \times 10^{-3}$ & 0.20 & $1.28 \times 10^{-2}$ & 0.23 \\
\hline \multirow{3}{*}{$\begin{array}{l}\text { Ologe } \\
\text { Lagoon }\end{array}$} & $\mathrm{EF}$ & $3.28 \times 10^{-3}$ & $1.02 \times 10^{-2}$ & $9.20 \times 10^{-4}$ & - & $1.91 \times 10^{-3}$ & $8.65 \times 10^{-1}$ & & \\
\hline & Igeo & -10.3 & -8.67 & -12.14 & -2.05 & -11.08 & -2.26 & & \\
\hline & $\mathrm{CF}$ & $1.19 \times 10^{-3}$ & $3.69 \times 10^{-3}$ & $3.33 \times 10^{-4}$ & 0.36 & $6.92 \times 10^{-4}$ & 0.31 & $6.97 \times 10^{-3}$ & 0.11 \\
\hline
\end{tabular}

$537 \quad \mathrm{EF}=$ Enrichment factor; Igeo $=$ Geoaccumulation index; $\mathrm{CF}=$ Contamination factor; PLI $=$ 538 Pollution load index; $\mathrm{mCd}=$ Modified degree of contamination

539

540

541

542

543

544

545

546

547

548 
549 Table 5: Mean quotients using the PEL and ERM values and heavy metal potential ecological 550 risk indices for Badagry Creek, River Owo and Ologe Lagoon

\begin{tabular}{llll}
\hline & \multicolumn{1}{c}{$\begin{array}{c}\text { Badagry Creek } \\
\left(\mathrm{E}_{\mathrm{r}}^{1}\right)\end{array}$} & \multicolumn{1}{c}{ River Owo } & \multicolumn{1}{c}{ Ologe Lagoon } \\
& $5.75 \times 10^{-4}$ & $\left(\mathrm{E}_{\mathrm{r}}^{1}\right)$ & $1.41 \times 10^{-3}$ \\
$\mathrm{Zn}$ & $2.52 \times 10^{-2}$ & $6.11 \times 10^{-3}$ & $1.48 \times 10^{-2}$ \\
$\mathrm{~Pb}$ & $4.50 \times 10^{-3}$ & $2.96 \times 10^{-2}$ & $2.50 \times 10^{-3}$ \\
$\mathrm{Cu}$ & $6.67 \times 10^{-3}$ & $3.50 \times 10^{-3}$ & $6.00 \times 10^{-3}$ \\
$\mathrm{As}$ & 6.90 & $9.33 \times 10^{-3}$ & 5.64 \\
$\mathrm{Cd}$ & 6.94 & 3.54 & 5.66 \\
\hline $\mathrm{R} 1$ & $4.77 \times 10^{-4}$ & 3.59 & $3.91 \times 10^{-4}$ \\
\hline m-PEL-Q & $2.49 \times 10^{-4}$ & $7.87 \times 10^{-4}$ & $2.11 \times 10^{-4}$ \\
m-ERM-Q & $4.62 \times 10^{-4}$ & \\
\hline
\end{tabular}

$\mathrm{m}-\mathrm{PEL}-\mathrm{Q}=$ Mean quotient using probable effect level; $\mathrm{m}-\mathrm{ERM}-\mathrm{Q}=$ Mean quotient using effect range-median

553

554

555

556

557

558

559

560

561

562

563

564

565

566

567

568

569

570

\subsection{Ecotoxicological assessment of heavy metal concentration in sediments}

The sediment contamination and potential ecotoxicological effects associated with the observed level of the metals were evaluated with two sets of standard quality guidelines (SQGs) (ERL/ERM and TEL/PEL) developed for aquatic ecosystems (MacDonald et al., 2000). The mean quotients using the PEL (m-PEL-Q) are $3.91 \times 10^{-4}, 4.77 \times 10^{-4}$ and $7.87 \times 10^{-4}$ for Ologe Lagoon, Badagry Creek and River Owo respectively. The trend was the same with mean quotients using ERM (mERM-Q); Ologe Lagoon $=2.11 \times 10^{-4}$, Badagry Creek $=2.49 \times 10^{-4}$ and River Owo $=4.62 \times 10^{-4}$ (Table 5).

\subsection{Potential Ecological Risks}

The potential ecological risk index (PERI) $\left(\mathrm{E}^{1}{ }_{\mathrm{r}}\right)$ for each metal at the sampling stations and the integrated ecological risk index $\left(\mathrm{R}_{1}\right)$ are shown in Table 5. The PERI of $\mathrm{Pb}\left(1.48 \times 10^{-2}\right)$ and As $\left(6.00 \times 10^{-3}\right)$ were lowest in Ologe Lagoon but highest $\left(\mathrm{Pb}=2.96 \times 10^{-2}\right.$, As $\left.=9.33 \times 10^{-3}\right)$ in River Owo. The PERI of $\mathrm{Zn}$ and $\mathrm{Cd}$ followed opposite trend; the lowest $\left(5.75 \times 10^{-4}\right)$ for $\mathrm{Zn}$ was recorded in Badagry Creek while the highest $\left(6.11 \times 10^{-3}\right)$ value occurred in River Owo, Cd had the lowest value (3.54) in River Owo and the highest (6.90) in Badagry Creek. The lowest $\left(2.50 \times 10^{-3}\right)$ and highest $\left(4.50 \times 10^{-3}\right)$ PERI for $\mathrm{Cu}$ were obtained in Ologe Lagoon and Badagry Creek respectively. 
571 The integrated ecological risk index for River Owo, Ologe Lagoon and Badagry Creek are 3.59,

5725.66 and 6.94 respectively.

573

574

575

576

577

578

579

580

581

582

583

584

585

586

587

588

\subsection{Health risk assessment of heavy metals}

The health risk associated with the consumption of the muscle of Coptodon zillii was evaluated by calculating the estimated dietary intake (EDI) and target hazard quotients (THQ) (Table 6). The EDI ranged from $0.00 \mathrm{mgkg}^{-1} \mathrm{day}^{-1}$ in $\mathrm{Pb}$ from River Owo to $1.15 \times 10^{-3} \mathrm{mgkg}^{-1} \mathrm{day}^{-1}$ in Fe still from River Owo. The EDI for $\mathrm{Zn}$ and $\mathrm{Cu}$ followed the same pattern as does $\mathrm{Pb}$ and $\mathrm{Cd}$ but the EDI for As was the same value $\left(8.41 \times 10^{-7} \mathrm{mgkg}^{-1} \mathrm{day}^{-1}\right)$ in all the sampling stations. Table 6 also shows the Total-THQ associated with the consumption of Coptodon zillii. The range of values of the THQs of the metals in Badagry Creek, River Owo and Ologe Lagoon are $1.23 \times 10^{-4}-1.65 \times 10^{-2}$, $0.00-1.64 \times 10^{-2}$ and $5.76 \times 10^{-5}-1.65 \times 10^{-2}$. The Total-THQs are Badagry Creek $\left(1.98 \times 10^{-2}\right)$, River Owo $\left(1.90 \times 10^{-2}\right)$ and Ologe Lagoon $\left(2.28 \times 10^{-2}\right)$.

Table 6: Estimated daily intake $\left(\mathrm{mgkg}^{-1} \mathrm{day}^{-1}\right)$ and estimated target hazard quotients (THQ) for individual metals and total THQ from consumption of Coptodon zillii from Badagry Creek, River Owo and Ologe Lagoon

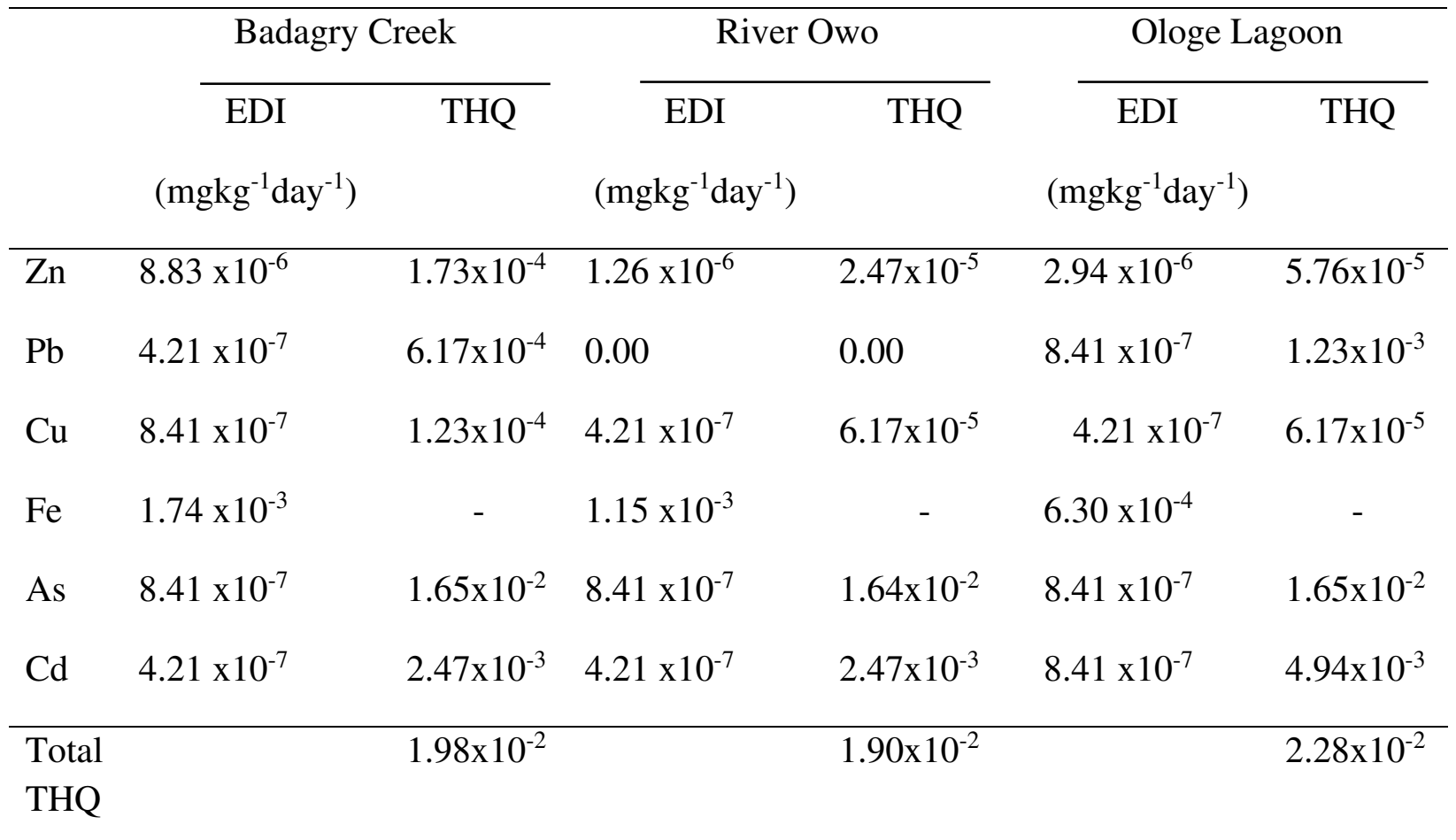




\subsection{DISCUSSION}

\subsection{Physicochemical parameters in water}

One of the indices used to assess aquatic ecosystem health is the physico-chemistry of the environment (O'Brien et al., 2016). A lot of the processes in aquatic ecosystem are driven by these water quality variables, which must be maintained within specific limits; otherwise the water body would be unable to provide its traditional services to man and its environment. The results of the physico-chemical parameters of this study conform to earlier studies on Badagry Creek and Ologe Lagoon in the Lagos Lagoon complex (Agboola et al., 2016, Kumolu-Johnson et al., 2010). Some of the water quality variables showed significant $(\mathrm{p}<0.05)$ variation among the sampling stations. These parameters are turbidity, electric conductivity, total dissolved solids, total solids and ammonia. Indeed, the values of turbidity and conductivity in this study have exceeded the World Health Organisation (WHO, 2008) standards for the culture of fish and other aquatic organisms. This observation might have been caused by sand mining activities in the sampling stations especially in Badagry Creek and Ologe Lagoon. Clarke et al. (2019) reported that the conductivity value is an indication of the quantity of dissolved ionic or dissolved organic substances in aquatic ecosystem, which can increase due to anthropogenic activities like sand dredging. Most of the water quality variables in this study are within the limits of the values recommended for the growth and survival of fish in tropical environment. Boyd (1998) suggested a temperature range of 20 $30^{\circ} \mathrm{C}$ and dissolved oxygen range of $3-4 \mathrm{mg} / \mathrm{l}$. World Health Organisation (2008) recommended $\mathrm{pH}$ of 5.5 - 9.0. Chlorophyll-a concentration is a measure of phytoplankton abundance and biomass (primary productivity) in water bodies. Badagry Creek and River Owo can be described as mesotrophic and Ologe Lagoon as eutrophic (Lang, 1985). The intense sand mining activity in Badagry Creek might have been responsible for the low chlorophyll-a (primary productivity) level observed in that station, although it was not significantly $(p>0.05)$ different from the values obtained in the other stations. Sand mining will increase turbidity which will result in increased extinction coefficient of the water body, and consequently light penetration will be reduced causing low primary productivity and low fisheries output. The physico-chemical variables of the sampling stations indicate that the water bodies have favourable conditions for occurrence, survival, growth and multiplication of most tropical fish species.

\subsection{Length-weight relationship and condition factor}

Length-weight relationship (LWR) and condition factor (K) are indices that are importance in aquatic ecosystem health assessment although they might not be in frequent use. Many fish stock assessment models use length and weight data. The growth coefficient (b) obtained from LWR is a reflection of the general condition of appetite and gonad content of fish (Pervin and Mortuza, 2008). Fish experiences increase in weight due to the utilization of food items that are available for growth and energy (Kamaruddin et al. 2012). The growth coefficient may also vary in response to other factors like growth phase, sex, gonad development and stomach contents (Hossain et al. 2006; Leunda et al. 2006). In the same vein, condition factor reflects the physiological state of fish in relation to its welfare (Kumolu-Johnson and Ndimele, 2010). The $\mathrm{K}$ value has very strong correlation with the LWR and as such, $b$ is important in the assessment of the well-being of fish, which is a reflection of the state of the environment of the fish. In the present study, the $b$ value of all the fish species from the three sampling stations were within the expected range of 2.5 to 3.5 (Froese, 2006). About $78 \%$ of the fish had negative allometric growth, 19\% isometric and 3\% 
positive allometric growth. The range of value of $b(2.478-3.183)$ obtained in this study is similar to the values (2.607-3.254) recorded by Agboola and Anetekhai (2008), which studied the lengthweight relationships of 35 fish species from Badagry Creek, Lagos. It is also similar to the b values (2.012 - 2.991) obtained by Kumolu-Johnson and Ndimele (2010) who worked on 21 fish species from Ologe Lagoon. Most of the fish species have $\mathrm{K}$ values outside the range $(2.9-4.8)$ recommended as suitable for matured fresh water fish by Bagenal and Tesch (1978). The percentage of conformity to this standard is $23 \%, 38 \%$ and $27 \%$ for Badagry Creek, River Owo and Ologe Lagoon respectively. However, most of the K>1.0 except Chrysichthys nigrodigitatus, Cynoglossus senegalensis, Mugil cephalus and Clarias gariepinus from Badagry Creek. Ogunola et al (2018) reported that fish with high $\mathrm{K}$ values (>1) are in a better environmental condition than those with low $\mathrm{K}$ values $(<1)$. High $\mathrm{K}$ values have been linked to several factors; availability and abundance of food or prey, high feeding intensity, good environmental conditions such as optimum temperature, high dissolved oxygen level, low or absence of predators, sustainable fishing practices, genetic and immunity, and self-regulatory systems (Idowu 2017; Guidelli et al. 2011; Abdul et al. 2016). The good condition of the fish species from the sampling stations could be due to the good quality of the water bodies evidenced in the reported physico-chemical parameters, which are within the limits considered adequate for tropical fish.

\subsection{Ecological indices of the sampling stations}

Biological diversity, abundance, tolerance and composition are community metrics frequently used in aquatic environment to assess ecosystem health. They have been used as either single or multi-metric indices to ascertain ecosystem integrity and guide management decisions (e.g. Chiu et al., 2011). Most of the diversity indices used in this study did not show much variation among the sampling stations, and they are similar to values reported in previous studies (Lawson and Olusanya, 2010; Alam et al., 2007; Jewel et al., 2018). The range of Shannon's diversity index $(2.03-2.37)$ recorded in this study is higher than the values $(0.74-0.85)$ reported by Lawson and Olusanya (2010) who worked on River Ore, South-west, Nigeria. However, the number of fish species reported in previous studies in these water bodies is higher than the values observed in this study. Agboola and Anetekhai (2008) reported 35 fish species from Badagry Creek against 13 species in this study. Kumolu-Johnson and Ndimele (2010) encountered 21 fish species, 11 was observed in the present study. Although, these previous studies did not use ecological indices to analyse their results, the absence of a good number of these species (more than 50\%) indicates that the environment may not be as conducive as it used to be or the fish stock has been over-exploited. Oral evidence from fishers in the sampling stations states that their catches have progressively dwindled over time forcing some of them to take up alternative or additional sources of livelihood. They attributed this to intense sand mining activities in the sampling stations. In addition, the presence of Agbara Industrial Estate in Ogun State, which empties its effluent into Ologe Lagoon and Badagry Creek could also be responsible for the loss in fish species and reduction in catch by fishers. Ndimele et al. (2017) reported that since 2013, there has been an increase in industrial effluent discharged into Ologe Lagoon and Badagry Creek from Agbara Industrial Estate because about 45 companies, each with a minimum investment of US\$100 million, have made Ogun state their abode with majority of them located in Agbara Industrial Estate. 


\subsection{Sediment pollution indices}

Sediment is very important in pollution studies because it acts as sink or reservoir of heavy metals in aquatic ecosystem (Ndimele and Kumolu-Johnson, 2012). The level of heavy metals in different compartments (water, sediment and biota) of the water bodies in Lagos metropolis has been increasing in the last twenty five years (Ndimele and Kumolu-Johnson, 2012). Agboola et al (2008) did not detect $\mathrm{Pb}$ in Badagry Creek. So, the presence of $\mathrm{Pb}$ in Badagry Creek and other wetlands in Lagos now suggest that metal levels are on the increase. This could be as a result of natural processes like weathering, biogenic sources, wind-borne soil particles, etc. Another factor that could be responsible for the observed metal increase in aquatic ecosystems in Lagos Lagoon complex is anthropogenic sources. Lagos and Ogun States are the industrial hubs in Nigeria, accounting for over $70 \%$ of industrial activities in the country (Ndimele et al, 2017). These industries discharge effluent into nearby water bodies, thus polluting them and rendering them unfit to provide services to man and his environment. Sediment pollution indices are used for assessment and classification of aquatic ecosystem for effective management. In the present study, enrichment factor (EF), geoaccumulation index (Igeo), contamination factor (CF), pollution load index (PLI) and modified degree of contamination $(\mathrm{mCd})$ were used. Based on the standard provided by Acevedo-Figueroa et al (2006), the three sampling stations have no enrichment since the EF of the metals are less than 1. The indices of geoaccumulation for the metals in the sediments of the sampling stations were all below 1 indicating that the water bodies are uncontaminated according to the classification of Muller (1969). The health status of the water bodies were further investigated by CF, PLI and $\mathrm{mCd}$. Tomlinson's contamination factors, pollution load indices and modified degrees of contamination of the metals in the sediments of the sites were <1. Håkanson (1980) opined that the degree of sediment metal contamination varies with location in any ecosystem. According to Håkanson classification, the water bodies have low contamination because the CF, PLI and $\mathrm{mCd}$ of all the metals were $<1$. They are similar to the values reported by Benson et al (2016) who worked on Douglas Creek, Qua Iboe estuary, Akwa-Ibom state, Southsouth, Nigeria. The low levels of CF, PLI and $\mathrm{mCd}$ in the sites imply that the aquatic ecosystems might not have been significantly contaminated by anthropogenic sources (Benson et al, 2016).

\subsection{Ecotoxicological assessment of heavy metal concentration in sediments}

The mean quotients calculated from the two SQGs using PEL and ERM values are used to compare metal pollution of the sediments of the water bodies. Long and MacDonald (1998) reported that mean ERM quotients are related to the degree or probability of toxicity. Mean ERM quotient of $<0.1$ has a $12 \%$ probability of toxicity; mean ERM quotient of $0.11-0.5$ has a $30 \%$ probability of being toxic; mean ERM quotient of $0.51-1.5$ has a $40 \%$ probability of toxicity and a mean ERM quotient of $>1.50$ has a $74 \%$ probability of toxicity. Going by this classification, all the sediment samples can be described as low priority sites with $12 \%$ probability of being toxic. Mean PEL quotient has a similar classification as mean ERM quotient. Low degree of contamination $(\leq 0.1)$, medium-low degree of contamination (0.11-1.5), high-medium degree of contamination (1.512.3), and high degree of contamination (>2.3) has $8 \%, 21 \%, 49 \%$ and $73 \%$ probability of being toxic respectively (Long et al, 2000). The mean PEL quotients $\left(3.91 \times 10^{-4}-7.87 \times 10^{-4}\right)$ obtained in the sediments of the studied sites are $<0.1$. Therefore, the sediments would have low degree of contamination with $8 \%$ probability of being toxic. 


\subsection{Potential Ecological Risks}

The risk factor $\mathrm{R}_{1}$ introduced by Hakanson (1980) used eight parameters $(\mathrm{Zn}, \mathrm{Pb}, \mathrm{Cu}, \mathrm{As}, \mathrm{Cd}, \mathrm{Cr}$, $\mathrm{Hg}$ and $\mathrm{PCB}$ ) but only five $(\mathrm{Zn}, \mathrm{Pb}, \mathrm{Cu}, \mathrm{As}$ and $\mathrm{Cd}$ ) were applied in this study. According to the Hakanson (1980) criteria for evaluation of ecological risk, none of the metals posed any threat at the studied sites because their potential ecological risk indices $\left(\mathrm{E}_{\mathrm{r}}^{1}\right)\left(5.75 \times 10^{-4}-6.90\right)$ are $<40$. However, $\mathrm{E}_{\mathrm{r}}^{1}$ for $\mathrm{Cd}$ was considerably higher than the values obtained for other metals. Yi et al (2011) opined that the high ecological risk of $\mathrm{Cd}$ in aquatic ecosystems is due to its high toxicresponse factor. The potential ecological risk indices for individual metals stressors $\left(\mathrm{E}^{1} \mathrm{r}\right)$ indicated that intensity of pollution of the five metals decreased in the following order: $\mathrm{Cd}>\mathrm{Pb}>\mathrm{As}>\mathrm{Cu}>\mathrm{Zn}$. $\mathrm{R}_{1}$ is a measure of the sensitivity of biological communities to toxic substances and shows the potential ecological risk caused by the metals combined. In the present study, $\mathrm{R}_{1}$ of the three sampling stations $(3.59-6.94)$ was $<95$, which implies that these aquatic ecosystems exhibited low ecological risks according to the standard by Hakanson (1980).

\subsection{Health risk assessment of heavy metals}

Two indices \{estimated dietary intake (EDI) and target hazard quotients (THQ) \} were used to assess the health risk associated with the consumption of Coptodon zillii from the sampling stations. The ranges of the EDIs for the metals across the sampling sites are: $\mathrm{Zn}\left(1.26 \times 10^{-6}-8.83\right.$ $\left.\mathrm{x} 10^{-6} \mathrm{mgkg}^{-1} \mathrm{day}^{-1}\right), \mathrm{Pb}\left(0.00-8.41 \times 10^{-7} \mathrm{mgkg}^{-1} \mathrm{day}^{-1}\right), \mathrm{Cu}\left(4.21 \times 10^{-7}-8.41 \times 10^{-7} \mathrm{mgkg}^{-1} \mathrm{day}^{-1}\right)$, As $\left(8.41 \times 10^{-7} \mathrm{mgkg}^{-1} \mathrm{day}^{-1}\right)$ and $\mathrm{Cd}\left(4.21 \times 10^{-7}-8.41 \times 10^{-7} \mathrm{mgkg}^{-1} \mathrm{day}^{-1}\right)$. These values are lower than the oral reference doses (RfDo) of the metals; $\mathrm{Zn}\left(3 \times 10^{-1} \mathrm{mgkg}^{-1} \mathrm{day}^{-1}\right), \mathrm{Pb}\left(4 \times 10^{-3} \mathrm{mgkg}^{-}\right.$ ${ }^{1}$ day $\left.^{-1}\right), \mathrm{Cu}\left(4 \times 10^{-2} \mathrm{mgkg}^{-1} \mathrm{day}^{-1}\right)$, As $\left(3 \times 10^{-4} \mathrm{mgkg}^{-1} \mathrm{day}^{-1}\right)$ and Cd $\left(1 \mathrm{x}^{-3} \mathrm{mgkg}^{-1} \mathrm{day}^{-1}\right)$ (USEPA, 2009), indicating that the consumption of Coptodon zillii from the studied sites is not likely going to cause a non-cancer health risk. In the same vein, THQs of the metals in all the sites was $<1$, also suggesting that people who consume the fish would not experience significant health risks due to intake of individual metals. The THQs were also lower than the RfDo further buttressing the nontoxic status of the Coptodon zillii from these water bodies. The estimated daily intakes for individual metals decreased in the following order: $\mathrm{Zn}>\mathrm{As}>\mathrm{Cu}>\mathrm{Cd}>\mathrm{Pb}$ while estimated target quotients followed this sequence: $\mathrm{As}>\mathrm{Cd}>\mathrm{Cu}>\mathrm{Zn}>\mathrm{Pb}$. The total THQ for the populace in each sampling location did not exceed 1. This further affirms the safety level of Coptodon zillii from the sites and their healthy nature.

\section{Conclusion}

Heavy metal pollution continues to present significant environmental challenge to communities around Lagos Lagoon Complex, Lagos, Nigeria because of the growing number of companies that discharge effluents into the lagoons. The implication is that the ecosystem services provided by these water bodies are threatened. More worrisome is the threat to the lives of the communities around the aquatics who depend on the lagoons for sustenance. In order to ascertain the health status of the aquatic ecosystems, a multi-indices approach is adopted because of the deficiency of single index methods. These indices include physico-chemistry, length-weight relationship, condition factor, fish diversity indices, sediment pollution indices, ecotoxicology of heavy metals in sediment and potential ecological risks as well as health risk assessment of heavy metals. This study showed that the three water bodies (Badagry Creek, Ologe Lagoon and River Owo) are healthy but regular monitoring is necessary for prompt detection of sudden changes that could affect aquatic and human lives around the areas. 
Declarations:

773 Ethics approval and consent to participate: Not Applicable

774

775

776

777

778

779

780

781

782

783

784
Consent for publication: Not Applicable

Availability of data and materials: The datasets used and/or analysed during the current study are available from the corresponding author on reasonable request.

Competing interests: The authors declare that they have no competing interests.

Funding: Not Applicable.

Authors' contributions:

\begin{tabular}{|l|l|}
\hline Activities & Personnel \\
\hline Conceptualization & $\begin{array}{l}\text { Ndimele, P.E; Owodeinde, F.G.; GiwaAjeniya, A.O.; } \\
\text { Moronkola, B.A. }\end{array}$ \\
\hline Data curation & $\begin{array}{l}\text { Ndimele, P.E; Owodeinde, F.G.; GiwaAjeniya, A.O.; } \\
\text { Moronkola, B.A.; Adaramoye, O.R.; Ewenla, L.O. and } \\
\text { Kushoro, H.Y. }\end{array}$ \\
\hline Formal analysis & $\begin{array}{l}\text { Ndimele, P.E; Owodeinde, F.G.; GiwaAjeniya, A.O.; } \\
\text { Moronkola, B.A. }\end{array}$ \\
\hline Investigation & $\begin{array}{l}\text { Ndimele, P.E; Owodeinde, F.G.; GiwaAjeniya, A.O.; } \\
\text { Moronkola, B.A.; Adaramoye, O.R.; Ewenla, L.O. and } \\
\text { Kushoro, H.Y. }\end{array}$ \\
\hline Methodology & $\begin{array}{l}\text { Ndimele, P.E; Owodeinde, F.G.; GiwaAjeniya, A.O.; } \\
\text { Moronkola, B.A. }\end{array}$ \\
\hline Project administration & Ndimele, P.E; Owodeinde, F.G. \\
\hline Resources & $\begin{array}{l}\text { Ndimele, P.E; Owodeinde, F.G.; GiwaAjeniya, A.O.; } \\
\text { Moronkola, B.A.; Adaramoye, O.R.; Ewenla, L.O. and } \\
\text { Kushoro, H.Y. }\end{array}$ \\
\hline Software & Adaramoye, O.R.; Ewenla, L.O. and Kushoro, H.Y. \\
\hline Supervision & Ndimele, P.E; Owodeinde, F.G. \\
\hline Validation & Adaramoye, O.R.; Ewenla, L.O. \\
\hline Visualization & Adaramoye, O.R.; Ewenla, L.O. \\
\hline Original draft & $\begin{array}{l}\text { Ndimele, P.E; Owodeinde, F.G.; GiwaAjeniya, A.O.; } \\
\text { Moronkola, B.A. }\end{array}$ \\
\hline Review \& editing & Ndimele, P.E; Owodeinde, F.G. \\
\hline & \multicolumn{1}{|l}{. } \\
\hline
\end{tabular}




\section{References}

Abdul WO, Omoniyi IT, Adekoya EO, Adeosun FI, Odulate OO, Idowu AA, Olajide AE, Olowe OS (2016) Length-weight relationship and condition factor of some commercial fish species in Ogun State Coastal Estuary, Nigeria. Ife J. Agric. 28(1): 1-9.

Abrahim GMS (2005) Holocene sediments of Tamaki Estuary: Characterization and impact of recent human activity on an urban estuary in Auckland, New Zealand, PhD Thesis University of Auckland, Auckland (New Zealand), 361pp.

Abubakar A, Uzairu A, Ekwumemgbo PA, Okunola OJ (2015) Risk assessment of heavy metals in imported frozen fish Scomber scombrus species sold in Nigeria: A case study in Zaria metropolis. Advances in Toxicology, ID 303245.

Acevedo-Figueroa D, Jimenez-Velez BD, Rodríguez-Sierra CJ (2006) Trace metals in sediment of two estuarine lagoons from Puerto Rico. Environmental Pollution 141(2): 336-42. DOI: $10.1016 / j . e n v p o l .2005 .08 .037$

Adaikpoh EO (2013) Distribution and enrichment of heavy metals in soils from waste dump sites within Imoru and environs, southwest Nigeria. J. Environ. Earth Sci. 3, 45-54.

Agboola JI, Anetekhai MA (2008) Length-weight relationships of some fresh and brackish water fishes in Badagry creek, Nigeria. Journal of Applied Ichthyology, 24(5): 623-625.

Agboola JI, Anetekhai MA, Denloye AA (2008) Aspects of the Ecology and Fishes of Badagry Creek (Nigeria). Journal of Fisheries and Aquatic Science 3(3): 184-194. DOI: $10.3923 /$ jas.2008.184.194.

Agboola JI, Ndimele PE, Odunuga S, Akanni A, Kosemani B, Ahove MA (2016) Ecological health status of the Lagos wetland ecosystems: Implications for coastal risk reduction. Estuarine, Coastal and Shelf Science 183: Part A, 73-81.

Alam A, Mustafa MG, Azad MAK (2007) Water and sediment quality and plankton diversity of Posna beel, Tangail. Bangladesh J. Fish. (Special Issue) 30: 177-188.

Ali MHH, Fishar MRA (2005) Accumulation of trace metals in some benthic invertebrates and fish species relevant to their concentrations in water and sediment of Lake Qarun, Egypt. Egyptian Journal of Aquatic Research 31: 289-301.

Aliyu A, Dada J, Adam I (2015) Current status and future prospects of renewable energy in Nigeria. Renewable and Sustainable Energy Reviews 48: 336-346.

American Public Health Association (APHA) (1985) Standard methods for the examination of water and waste water. 16th edition. American Public Health Association, Washington, D.C. 1268 pp. 
Asano S, Eto K, Kurisaki E, Gunji H, Hiraiwa K, Sato M, Sato H, Hasuike M, Hagiwara N, Wakasa H (2000) Acute inorganic mercury vapor inhalation poisoning. Pathol. Int. 50: 169 -174.

Bagenal TB, Tesch FW (1978) Age and growth. In: T.B. Bagenal (Ed) Methods for the assessment of fish production in fresh waters. Blackwell Scientific Publication, Oxford, pp. 101-136.

Benson NU, Anake WU, Essien JP, Enyong P, Olajire AA (2016) Distribution and risk assessment of trace metals in Leptodius exarata, surface water and sediments from Douglas Creek, Qua Iboe estuary. Journal of Taibah University for Science 11(3): 434-449. http://dx.doi.org/10.1016/j.jtusci.2016.08.004

Bowen HJM (1979) Environmental chemistry of the elements. Adacemic Press, London, 333.

Boyd CE (1998) Water quality for pond aquaculture. Res. Develop. 43: 1-11.

Chen JC, Sun ZZ, Qu JH, Wu W, Hu GD (2002) Water Pollution and its toxicity to fishes in the major areas of the lower researches of the Yangtze River. Acta Hydrobiologica Sinica 26 (6): 635-640 (in Chinese).

Chiu GS, Guttorp P, Westveld AH, Khan SA, Jun L (2011) Latent health factor index: a statistical modeling approach for ecological health assessment. Environmetrics 22: 243-255.

Clarke EO, Ndimele PE, Mekuleyi GO, Disu MO (2019) Ecological impacts of sand mining on some aspects of the fisheries of Lagos Lagoon, Lagos State, Nigeria. Nigerian Journal of Fisheries and Aquaculture 7(1): 31-39.

Food and Agriculture Organization of the United Nations (FAO) (2015) Food balance sheet of fish and fishery products in live weight and fish contribution to protein supply: 2011 world by continent. Available: http://faostat3.fao.org/browse/FB/FBS/E, 2015. [Accessed: 13 November, 2019].

Froese R (2006) Cube law, condition factor and weight-length relationships: History, metaanalysis and recommendations. J. Appl. Ichthyol., 22: 241-253.

Guidelli G, Tavechio WLG, Takemoto RM, Pavanelli GC (2011) Relative condition factor and parasitism in anostomid fishes from the floodplain of the Upper Parana River, Brazil. Vet. Parasitol.177: 145-51.

Håkanson L (1980) An ecological risk index for aquatic pollution control of sediment ecological approach. Water Research 14: 975-1000.

Hallenbeck WH (1993) Quantitative risk assessment for environmental and occupational health. Lewis, Chelsea, MI. 
Hossain MY, Ahmed ZF, Leunda PM, Jasmine S, Oscoz J, Miranda R, Ohtomi J (2006) Condition, length-weight and length-length relationships of the Asian striped catfish Mystus vittatus (Bloch, 1794) (Siluriformes: Bagridae) in the Mathabhanga River, Southwestern Bangladesh. Journal of Applied Ichthyology 22: 304-307.

Iavicoli I, Fontana L, Bergamaschi A (2009) The Effects of Metals as Endocrine Disruptors. Journal of Toxicology and Environmental Health Part B. 12(3): 206-223. DOI: $10.1080 / 10937400902902062$

Idowu EO (2017) Aspects of the reproductive biology of African pike characin fish, Hepsetus odoe (Bloch 1794) in an artificial lake, Nigeria. Agric. Sci Res. J. 7(4): 154-62.

Jewel MAS, Haque MA, Khatun R, Rahman MS (2018) A Comparative Study of Fish Assemblage and Diversity Indices in two Different Aquatic Habitats in Bangladesh: Lakhandaha Wetland and Atari River. Jordan Journal of Biological Sciences 11: 427-434.

Johnston EL, Mayer-Pinto M, Crowe TP (2015) Chemical contaminant effects on marine ecosystem functioning. J. Appl. Ecol. 52: 140-149.

Kamaruddin IS, Mustafa-Kamal AS, Christianus A, Daud SK, Amin SMN, Yu-Abit L (2012) Length-weight relationship and condition factor of three dominant species from the Lake Tasik Kenyir, Terengganu, Malaysia. Journal of Fisheries and Aquatic Science 6(7): 852856.

Keeler BL, Polasky S, Brauman KA, Johnson KA, Finlay JC, O’Neill A, Kovacs K, Dalzell B (2012) Linking water quality and well-being for improved assessment and valuation of ecosystem services. Proc. Natl. Acad. Sci. 109: 18619-18624.

Kummu M, de Moel H, Porkka M, Siebert S, Varis O, Ward PJ (2012) Lost food, wasted resources: global food supply chain losses and their impacts on freshwater, cropland, and fertiliser use. Sci. Total Environ. 438: 477-789.

Kumolu-Johnson CA, Ndimele PE (2010) Length-weight relationships and condition factors of twenty-one fish species in Ologe Lagoon, Lagos, Nigeria. Asian Journal of Agricultural Sciences 2(4): 174-179.

Kumolu-Johnson CA, Ndimele PE Akintola SL, Jibuike CC (2010) Copper, zinc and iron concentrations in water, sediment and Cynothrissa mento (Regan, 1917) from Ologe Lagoon, Nigeria: a preliminary survey. African Journal of Aquatic Science 35(1): 87-94.

Lang C (1985) Eutrophication of Lake Geneva indicated by the oligochaete communities of the profundal. Hydrobiologia 126: 237-243. https://doi.org/10.1007/BF00007501 
Lawson EO, Olusanya OM (2010) Fish Diversity in Three Tributaries of River Ore, South West, Nigeria. World Journal of Fish and Marine Sciences 2 (6): 524-531.

Leunda PM, Oscoz J, Miranda R (2006) Length-weight relationships of fish tributaries of the Ebro River, Spain. Journal of Applied Ichthyology 22: 299-300.

Leveque C, Paugy D, Teugels GG (1990) Faune des poissons d'eaux douces et saumatres de l'Afrique de l'Ouest. Paris, pp: 910.

Long ER, MacDonald DD (1998) Recommended uses of empirically derived, sediment quality guidelines for marine and estuarine ecosystems. Human and Ecological Risk Assessment 5: 1019-1039.

Long ER, MacDonallad DD, Severn CG, Hong CB (2000) Classifiying probabilities of acute toxicity in marine sediments with empirically derived sediment quality guideline. Environ. Toxicol. Chem. 19: 2598-2601.

Long ER, MacDonald DD, Smith SL, Calder FO (1995) Incidence of adverse biological effects within ranges of chemical concentrations in marine and estuarine sediments. Environmental Management 19: 81-97.

MacDonald DD, Ingersoll CG, Berger TA (2000) Development and evaluation of consensus-based sediment quality guidelines for fresh- water ecosystems. Arch. Environ. Contam. Toxicol. 39: 20-31.

Maceda-Veiga A, Monroy M, De Sostoa A (2012) Metal bioaccumulation in the Mediterranean barbell (Barbus meridionalis) in a Mediterranean River receiving effluents from urban and industrial wastewater treatment plants. Ecotoxicology Environmental Safety 76: 93-101.

Mediolla LL, Domingues MCD, Sandoval MRG (2008) Environmental assessment of an active tailings pile in the state of Mexico (Central Mexico). Research Journal of Environmental Sciences 2(3): 197-208.

Mendil D, an Uluözlü DÖ, an Hasdemir E, Tüzen M, Sari H, Suiçmez M (2005) Determination of trace metal levels in seven fish species in lakes in Tokat, Turkey. Food Chemistry 90: 175179.

Muller G (1969) Index of geoaccumulation in the sediments of the Rhine River. Geojournal 1(2): 108-118.

Nasir UP, Harikumar PS (2011) Ecotoxicity and ecosystem health of a Ramsar Wetland System of India. Journal of Environmental Protection 2: 710-719. 
Ndimele PE (2012) The Effects of water hyacinth (Eichhornia crassipes [Mart.] Solms) infestation on the physico-chemistry, nutrient and heavy metal content of Badagry Creek and Ologe Lagoon, Lagos, Nigeria. Journal of Environmental Science and Technology 5(2): 128-136.

Ndimele PE, Jenyo-Oni A, Jibuike CC (2009) The levels of lead $(\mathrm{Pb})$ in water, sediment and a commercially important fish species (Chrysichthys nigrodigitatus) (Lacepède, 1803) from Ologe Lagoon, Lagos, Nigeria. Journal of Environmental Extension 8: 70-75.

Ndimele PE, Kumolu-Johnson CA (2012) Some aspects of the physicochemistry and heavy metal content of water, sediment and Cynothrissa mento (Regan, 1917) from Badagry Creek, Lagos, Nigeria. Trends in Applied Sciences Research 7(9): 724-736.

Ndimele PE, Kumolu-Johnson CA (2011) Preliminary study on physico-chemistry and comparative morphometric characterisation of Cynothrissa mento (Regan, 1917) from Ologe, Badagry and Epe Lagoons, Lagos, Nigeria. International Journal of Agricultural Research 6 (10): 736-746.

Ndimele PE, Pedro, MO, Agboola JI, Chukwuka KS, Ekwu AO (2017) Heavy metal accumulation in organs of Oreochromis niloticus (Linnaeus, 1758) from industrial effluent-polluted aquatic ecosystem in Lagos, Nigeria. Environmental Monitoring and Assessment 189: 255.

O’Brien A, Townsend K, Hale R, Sharley D, Pettigrove V (2016) How is ecosystem health defined and measured? A critical review of freshwater and estuarine studies. Ecol. Indic. 69: 722729.

Ogunola OS, Onada, OA, Falaye AE (2018) Preliminary evaluation of some aspects of the ecology (growth pattern, condition factor and reproductive biology) of African pike, Hepsetus odoe (Bloch 1794), in Lake Eleiyele, Ibadan, Nigeria. Fisheries and Aquatic Sciences 21: 12.

Oliva M, Perales JA, Gravato C, Guilhermino L, Galindo-Riaño MD (2012) Biomarkers responses in muscle of Senegal sole (Solea senegalensis) from a heavy metals and PAHs polluted estuary. Marine Pollution Bulletin 64(10): 2097-2108.

Oyelaran-Oyeyinka B (1997) Industrial technology policy - making and implementation in Nigeria: an assessment. NISER Occasional Paper. Ibadan: NISER.

Palmer MA, Febria CM (2012) The heartbeat of ecosystems. Science 336 (6087): 1393-1394. DOI: $10.1126 /$ science. 1223250

Pauly D (1983) Some simple methods for the assessment of tropical fish stocks. FAO Fisheries Tech. Pap., FAO. Rome, 234: 52. 
Pervin MR, Mortuza MG (2008) Notes on length-weight relationship and condition factor of fresh water fish, Labeo boga (Hamilton) (Cypriniformes: Cyprinidae). University Journal of Zoology Rajshahi University 27: 97-98. DOI: 10.3329/ujzru.v27i0.1964

Pielou EC (1966) Species diversity and pattern diversity in the study of ecological succession. J. Theor. Biol. 3: 131-144.

Rickter WE (1973) Linear regressions in fisheries research. J. Fish. Res. Board Can. 30(3): 409434.

Sary A, Mohammadi M (2012) Mercury concentrations in commercial fish from freshwater and saltwater. Bull. Environ. Contam. Toxicol. 88: 162.

Schneider W (1992) FAO species identification sheets for fishery purposes field guide to the commercial marine resources of the Gulf of Guinea. FAO, Rome, pp: 268.

Shannon CE, Wiener W (1949) The mathematical theory of communication. Urbana, University of Illinois Press, p. 177.

Simpson EH (1949) Measurement of diversity. Nature 163: 688.

Sokal R, Rohlf F (1987) Introduction to biostatistics, 2nd Edn., Freeman Publication, New York, pp: 887.

Tomlinson DC, Wilson JG, Harris CR, Jeffery DW (1980) Problems in the assessment of heavy metals levels in estuaries and the formation of a pollution index. Helgol Wiss Meeresunters 33 (1-4): 566-575. doi:10.1007/BF02414780

Türkmen A, Tepe Y, Türkmen M, Mutlu E (2009) Heavy metal contaminants in tissues of the Garfish, Belone belone L., 1761, and the Bluefish, Pomatomus saltatrix L., 1766, from Turkey waters. Bulletin of Environmental Contamination Toxicology 82(1): 70-74.

Türkmen M, Türkmen A, Tepe Y, Ateş A, Gökkuş K (2008) Determination of metal contaminations in sea foods from Marmara, Aegean and Mediterranean seas: Twelve fish species. Food Chemistry 108(2): 794-800.

United States Environmental Protection Agency (USEPA) (2007) Microwave assisted acid digestion of sediments, sludge, soils and oils. Washington, DC: USEPA.

United States Environmental Protection Agency (USEPA) (2009) Risk-based concentration table. Philadelphia PA: United States Environmental Protection Agency, Washington, DC. 
994 995 996 997 998

Varol M (2011) Assessment of heavy metal contamination in sediments of the Tigris River (Turkey) using pollution indices and multivariate statistical techniques. Journal of Hazardous Materials 195: 355-364.

Vilmi A, Karjalainen SM, Nokela T, Tolonen K, Heino J (2016) Unravelling thedrivers of aquatic communities using disparate organismal groups and different taxonomic levels. Ecol. Indic.,: 108.

Wang HH, Li LQ, Wu XM, Pan GX (2006) Distribution of Cu and Pb in particle size fractions of urban soils from different city zones of Nanjing, China. J. Environ. Sci. (China) 18: 482487.

Wang XL, Sato T, Xing BS, Tao S (2005) Health risks of heavy metals to the general public in Tianjin, China via consumption of vegetables and fish. Science of the Total Environment 350: $28-37$.

World Health Organization, (2008). World health statistics (2008) Geneva, (http://www.who.int/whosis/ whostat/2008/en/index.htm, accessed 7 April 2019).

Yi Y, Yang Z, Zhang S (2011) Ecological risk assessment of heavy metals in sediment and human health risk assessment of heavy metals in fishes in the middle and lower reaches of the Yangtze River basin. Environmental Pollution 159: 2575-2585.

Yoshida T, Yamauchi H, Fan Sun G (2004) Chronic health effects in people exposed to arsenic via the drinking water: dose - response relationships in review. Toxicology and Applied Pharmacology 198: $243-252$.

Zar JH (1984) Biostatistical analysis. Prentice Hall, New Jersey, pp: 718.

Zhao S, Feng C, Quan W, Chen X, Niu J, Shen Z (2012) Role of living environments in the accumulation characteristics of heavy metals in fishes and crabs in the Yangtze River Estuary, China. Marine Pollution Bulletin 64(6): 1163-1171.

Zrnčić S, Oraić D, Ćaleta M, Mihaljević Ž, Zanella D, Bilandžić N (2013) Biomonitoring of heavy metals in fish from the Danube River. Environmental Monitoring and Assessment 185: 1189-1198. 
Figures

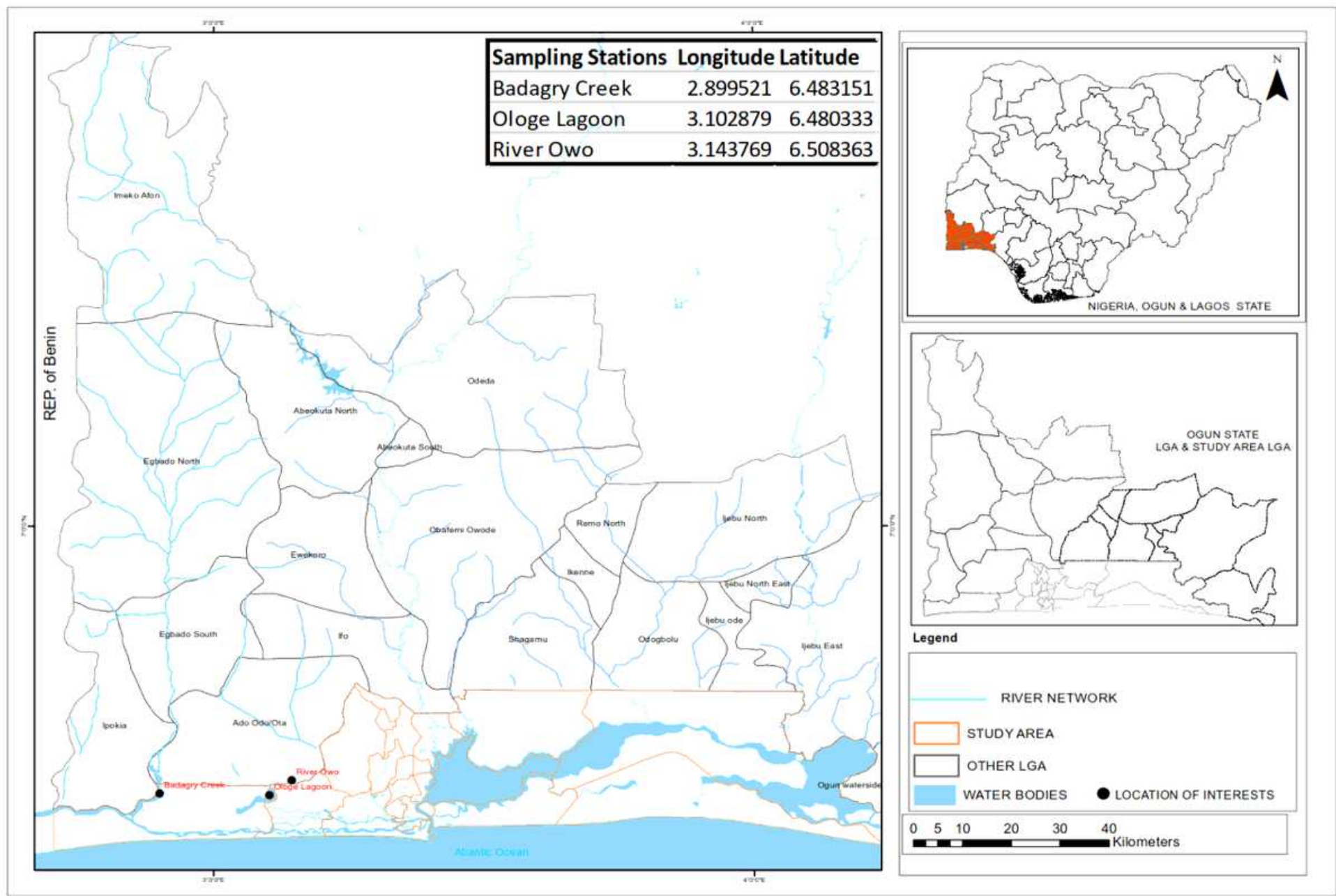

Figure 1

Map of study area showing sampling sites (River Owo, Ologe Lagoon and Badagry Creek) 